\title{
2 Cohort-specific serological recognition of SARS-CoV-2 variant RBD antigens
}

3 Douglas D. Fraser ${ }^{a, b, c, d}$, Michael R. Miller ${ }^{a, b}$, Claudio M. Martinn,e, Marat Slessarev ${ }^{b, e}$, Paul Hahn ${ }^{f}$, Ian Higgins,

4 Christopher Melo ${ }^{f}$, Michael A. Pest ${ }^{\dagger}$, Nate Rothery ${ }^{f}$, Xiaoqin Wang ${ }^{f}$, Johannes Zeidler ${ }^{f}$, Jorge A. Cruz-Aguado ${ }^{* *}$.

5 a. Lawson Health Research Institute, London, ON N6C 2R5, Canada

6 b. Department of Pediatrics, Western University, London, ON N6A 3K7, Canada

7 c. Department of Clinical Neurological Sciences, Western University, London, ON N6A 3K7, Canada

8 d. Department of Physiology \& Pharmacology, Western University, London, ON N6A 3K7, Canada

9 e. Lawson Health Research Institute, London, ON N6C 2R5, Canada

10 f. Diagnostics Biochem Canada Inc, London, ON N6M 1A1, Canada

$11{ }^{*}$ Corresponding author.

\section{Abstract}

Background: Estimating the response of different cohorts (e.g. vaccinated or critically ill) to new SARS-CoV-2 variants is important to customize measures of control. Thus, our goal was to evaluate binding of antibodies from sera of infected and vaccinated people to different antigens expressed by SARS-CoV-2 variants.

Methods: We compared sera from vaccinated donors with sera from four patient/donor cohorts: critically ill patients admitted to an intensive care unit (split in sera collected between 2 and 7 days after admission and more than ten days later), a NIBSC/WHO reference panel of SARS-CoV-2 positive individuals, and ambulatory or hospitalized (but not critically ill) positive donors. Samples were tested with an anti-SARS-CoV-2 lgG serological assay designed with microplates coated with a SARS-CoV-2 RBD recombinant antigen. The same sample sets were also tested with microplates coated with antigens harbouring RBD mutations present in eleven of the most widespread variants.

Results: Sera from vaccinated individuals exhibited higher antibody binding $(P<0.001)$ than sera from infected (but not critically ill) individuals when tested against the WT and each of 11 variants' RBD.

The optical density generated by sera from non-critically ill convalescence individuals upon binding to variant's antigens was different $(\mathrm{P}<0.05)$ from that of the WT in some variants-noteworthy, Beta, Gamma, Delta, and Delta Plus variants.

Conclusions: Understanding differences in binding and neutralizing antibody titers against WT vs variant RBD antigens from different donor cohorts can help design variant-specific immunoassays and complement other diagnostic and clinical data to evaluate the epidemiology of new variants.

Key Words: COVID-19; SARS-CoV-2 vaccine; SARS-CoV-2 variants; RBD mutations; antibody specificity; 
medRxiv preprint doi: https://doi.org/10.1101/2022.01.10.21268250; this version posted January 11, 2022. The copyright holder for this preprint (which was not certified by peer review) is the author/funder, who has granted medRxiv a license to display the preprint in perpetuity.

\section{Introduction}

The race to understand the impact of new variants of the SARS-CoV-2 virus on the effectiveness of antibody therapeutics, vaccines, and infection-elicited antibody responses has led to an unprecedented number of converging studies, the majority showing that most potent 'immune escape' mutations are in the receptorbinding motif (RBM), a region located within the receptor binding domain (RBD) of SARS-CoV-2's spike protein [1]. Indeed, approximately $90 \%$ of plasma or serum neutralizing antibody activity targets the RBD [2] and structural data support that RBD-based vaccines have a competitive position to deliver a fast response to the COVID-19 pandemic [3].

Until now, a trend has been delineated for the most frequent Variants of Concern (VOC) B.1.1.7 (Alpha), B.1.351 (Beta), P.1 (Gamma) and B1.617.2 (Delta) [4]. Some reports concur that sera from vaccinated or COVID-19 convalescent patients can efficiently neutralize viruses with just the N501Y mutation in the RBD, however, variants including the E484K mutation render sera from both wild type (WT) infected and vaccinated patients less efficient at virus neutralization [4-9]. Variants with sentinel mutation N439K decrease the activity of both polyclonal convalescent sera and monoclonal antibodies from individuals recovering from infection [10]. Another RBD mutation, L452R, present in variants B.1.429 and B.1.427 (Epsilon), and Indian Delta variant B.1.617.2 (Table 1), is thought to increase viral infectivity and potentially promote viral replication [11-15].

The published research, however, has scarcely addressed differences between naturally infected individuals of the general population, critically ill hospitalized patients, and vaccinated subjects in the response to new variants.

Personalizing the response to new variants of the virus is important to optimize measures of control; for example, as precautionary warnings for travel within regions with a prevalent variant, or to better triage the selection of individuals who should be prioritized for vaccination. Although neutralization assays could provide answers to those questions, they are expensive and time consuming for practical testing of the population.

In this study, we set out to investigate first, how the recognition pattern of WT SARS-CoV-2 RBD antibodies generated by vaccination distinguishes those patients compared to the recognition pattern of individuals after infection, and furthermore, determine how this recognition pattern differs when these antibodies are presented with the mutated variant-associated SARS-CoV-2 RBD proteins. Secondly, we aimed to examine whether recognition of variant specific RBD differs between vaccine sera and antibodies produced by different postinfection cohorts, information that could complement clinical data with variant-specific immunoassay-based 
medRxiv preprint doi: https://doi.org/10.1101/2022.01.10.21268250; this version posted January 11, 2022. The copyright holder for this preprint (which was not certified by peer review) is the author/funder, who has granted medRxiv a license to display the preprint in perpetuity.

All rights reserved. No reuse allowed without permission.

64

65

66

67

68

69

70

71

72

73

74

75

76

77

78

79

80

81

82

83

84

85

86

87

88

89

90

screenings to evaluate the potential epidemiological impact of new variants on previously infected and vaccinated cohorts.

\section{Methods}

\section{Study population and Ethics}

We used SARS-CoV-2 serum positive samples from:

a) Donors vaccinated with mRNA vaccines. Commercial samples from individuals who were vaccinated with two doses of either the Moderna mRNA-1273 or the Pfizer BioNTech COVID-19 vaccines during the first 3 months of 2021. The donor's serum was collected before and after the first and second doses.

b) Critically-ill patients (split in sera collected between 2 and 7 days after admission and more than ten days later). Samples came from patients admitted to the level-3 academic ICU at London Health Sciences Centre (London, Ontario), confirmed as COVID-19 with standard hospital testing by detection of two SARS-CoV-2 viral genes using polymerase chain reaction [16].

c) NIBSC/WHO reference panel of SARS-CoV-2 positive donors from the NIBSC/WHO reference panels.

d) Non-critically ill positive patient samples. Commercial samples were collected during 2020. Donors were ambulatory or hospitalized patients (AHP) COVID-19 positive based on RT-PCR tests and immunoassays and tested again with the ELISA kit of this study. Three donors were hospitalized (not critically ill) and released.

Commercial samples were sourced through Access Biologicals (Vista, California, USA), Lampire Biological Laboratories (Pipersville, PA, USA), or Plasma Services Group, Inc (Moorestown, NJ, USA), each of which confirmed patient consent and participation in an Institutional Review Board (IRB) approved protocol. For critically ill patient recruitment, waived consent was approved for a short, defined period (Western University, Research Ethics Board [REB] number 1670). Samples obtained through the WHO database were originally collected under WHO protocols and ethical considerations, and specifics are publicly available online via links provided in S4. Ultimately, all patient samples were approved for research use by their respective sources. Furthermore, all samples were assigned arbitrary Sample ID's to further anonymize personal data. Additional information available on request.

Samples were collected in North America before the global spread of the variants. We inferred that most of the studied positive specimens harbored antibodies raised against the WT virus, likely WA1/2020 (summarized in 
medRxiv preprint doi: https://doi.org/10.1101/2022.01.10.21268250; this version posted January 11, 2022. The copyright holder for this preprint (which was not certified by peer review) is the author/funder, who has granted medRxiv a license to display the preprint in perpetuity.

All rights reserved. No reuse allowed without permission.

91 Table 1). More detailed information about each sample and the demographics, infection/vaccination timeline,

92 and patient outcomes can be viewed in Supplemental Tables S1-S4.

93

94 Table 1. Summary of serum specimens used in this study. Additional patient data provided in Supplemental 95 Material (Tables S1-S5).

\begin{tabular}{|c|c|c|c|c|c|c|c|}
\hline \multirow[t]{3}{*}{ Cohort } & \multirow{3}{*}{$\begin{array}{l}\text { Number } \\
\text { of } \\
\text { serum } \\
\text { samples }\end{array}$} & \multirow{2}{*}{\multicolumn{2}{|c|}{ Age range }} & \multicolumn{3}{|c|}{$\begin{array}{l}\text { Number of days between } \\
\text { vaccine immunization or } \\
\text { detected infection and blood } \\
\text { draw }\end{array}$} & \multirow{3}{*}{$\begin{array}{l}\text { Date of last } \\
\text { drawn } \\
\text { sample }\end{array}$} \\
\hline & & & & \multirow{2}{*}{ Median } & \multicolumn{2}{|l|}{ Range } & \\
\hline & & Minimum & Maximum & & Lowest & Highest & \\
\hline Vaccinated & 60 & 19 & 76 & 14 & 12 & 17 & $\begin{array}{l}\text { April } 6^{\text {th }} \text {, } \\
2021\end{array}$ \\
\hline ICU patients, 2 - 7 days & 30 & 37 & 85 & $4.5^{\mathrm{a}}$ & 2 & 7 & $\begin{array}{l}\text { August } 10^{\text {th }} \text {, } \\
2020\end{array}$ \\
\hline ICU patients, $10+$ days & 15 & 45 & 77 & $16^{a}$ & 10 & 37 & $\begin{array}{l}\text { August } 10^{\text {th }} \text {, } \\
2020\end{array}$ \\
\hline WHO reference panel & 31 & \multicolumn{2}{|l|}{ Unknown } & \multicolumn{3}{|c|}{ At least 28 days } & $\begin{array}{l}\text { June } 26^{\text {th }} \text {, } \\
2020\end{array}$ \\
\hline $\begin{array}{l}\text { Ambulatory and } \\
\text { hospitalized population } \\
(\mathrm{AHP})^{\mathrm{b}}\end{array}$ & 37 & 24 & 81 & 38 & 10 & 119 & $\begin{array}{l}\text { July } 20^{\text {th }} \\
2020\end{array}$ \\
\hline
\end{tabular}

a Number of days after ICU admission; b 34 ambulatory and 3 hospitalized (but not critically ill) patients.

\section{Immunoassays}

Anti-SARS-CoV-2 IgG antibodies were detected with an enzyme-linked immunosorbent assay (ELISA) kit (DBC anti-SARS-CoV-2 ELISA, DBC-IGG-19) with interim authorization by Health Canada. In brief, the ELISA based assays were designed against antigens formulated by recombinant proteins (aa 319-541) created from the WT RBD sequence (original manufacturer's ELISA design) or those representing the RBD of prevalent VOCs (Table 2) with their various mutation sets (N501Y, K417N-E484K-N501Y, K417T-E484K-N501Y, L452R, L452RE484Q, L452R-T478K, K417NL452R-T478K, N439K, Y453F, S477N, K417T).

104 The original WT assay (CAN-IGG-19) uses a ratio between the optical density (OD) of the sample and the cut105 off [Ratio = OD of sample / Cut-Off] to determine a 'positive' vs 'negative' result, where the Cut-Off [Cut-Off $106(\mathrm{CO})=($ Mean of 3 Negative Control results $) \times$ factor 1.5$]$ is used to generate a ratio which is then interpreted 107 as a Positive (Ratio $\geq 1.2$ ), Negative (Ratio $\leq 1.0$ ), or Borderline (Ratio $1.0-1.2$ ) result. 
medRxiv preprint doi: https://doi.org/10.1101/2022.01.10.21268250; this version posted January 11, 2022. The copyright holder for this preprint (which was not certified by peer review) is the author/funder, who has granted medRxiv a license to display the preprint in perpetuity.

All rights reserved. No reuse allowed without permission.

108 In this study, the ratio was used only to compare the results between cohorts within the same antigen. When

109 comparisons were made between antigens, we used the optical density (OD) generated by the binding of

110 samples' antibodies to the antigens (rather than the ratio); in this way isolating the antigen-antibody interaction

111 and avoiding bias generated by differences in binding between the antigens and the negative control.

112 More details on the layout and performance of the original test can be found in [16] and in the kit's IFU

113 (https://dbc-labs.com/products/elisa/anti-sars-cov-2-igg/).

114 DiaSorin Liaison SARS-CoV-2 S1/S2 IgG results were provided by the sample supplier.

\section{Neutralization antibodies study}

116 To establish the validity of the DBC-IGG-19 ELISA kit to detect neutralizing antibodies we ran a comparison

117 study against Genscript cPass $^{\mathrm{TM}}$ SARS-CoV-2 Neutralization Antibody Detection/Surrogate Virus

118 Neutralization Test Kit (NJ, USA). This assay was previously validated against plaque reduction neutralization

119 tests PRNT50 and PRNT90 with 100\% agreement (See manual for SARS-CoV-2 Surrogate Virus Neutralization

120 Test Kit).

121 The samples were run with both the Genscript Kit and the DBC ELISAs for each of the WT and variants listed

122 above following the instructions for use of each test.

\section{Variant-specific immunoassays}

124 To test the binding of antibodies to mutated antigens, microplates were coated with recombinant RBD 125 harbouring mutations present in 11 of the most widespread variants of the virus to date (Table 2). The 126 expression system used to generate the mutant antigen RBD was identical to that of the previously released 127 DBC kit (DBC-IGG-19) with the only difference being the mutations themselves. The mutated antigens were 128 coated under the same conditions used for the WT antigen currently in the commercial anti-SARS-CoV-2 IgG 129 immunoassay. All other reagents of the variant kits used and serological test conditions remained the same as 130 the WT unaltered assay (DBC-IGG-19). 
medRxiv preprint doi: https://doi.org/10.1101/2022.01.10.21268250; this version posted January 11, 2022. The copyright holder for this preprint (which was not certified by peer review) is the author/funder, who has granted medRxiv a license to display the preprint in perpetuity.

All rights reserved. No reuse allowed without permission.

Table 2. Classification of the variants and RBD mutations associated with the antigens of this study.

\begin{tabular}{|l|l|l|l|l|}
\hline Variant & Lineage (PANGO) & $\begin{array}{l}\text { Clade } \\
\text { (GISAID) }\end{array}$ & RBD mutations & $\begin{array}{l}\text { Country of first } \\
\text { detection }\end{array}$ \\
\hline Wild Type & B & G & - & China \\
\hline Alpha & B.1.1.7 & GRY & N501Y & United Kingdom \\
\hline Beta & B.1.351/501Y.V2 & GH & K417N, E484K and N501Y & South Africa \\
\hline Gamma & P.1/B.1.1.28.1. & GR & K417T, E484K, and N501Y & Brazil \\
\hline Epsilon & B.1.427/429 & GH & L452R & Denmark \\
\hline Kappa & B.1.617.1 & G & L452R, E484Q & India \\
\hline Delta & B.1.617.2 & G & L452R, T478K & India \\
\hline Delta Plus & B.1.617.3 & G & K417N, L452R, T478K & India \\
\hline N439K & B.1.141/B.1.258 & GR & N439K & United Kingdom \\
\hline Y453F & N/A & N/A & Y453F & Denmark \\
\hline S477N & B.1.526.2/B1.1.25 & 20.C & S477N & Australia \\
\hline K417T & N/A & N/A & K417T & Brazil \\
\hline
\end{tabular}

\section{Statistical Analysis}

Statistical analysis was performed using Analyse-it software (Analyse-it Software, Ltd. (UK); https://analyseit.com/). Univariate group comparisons with non-parametric Steel pairwise ranking were calculated to compare variants within each cohort (figure 2) and cohorts within each variant (figure 3). P-values at the $5 \%$ significance

141 level were used to establish differences between variables.

142 We compared the results of WT antigen to antigens with RBD mutations within each patient cohort based on optical density (OD) which represents binding between antibodies in patient samples and the presented antigen

144 (i.e. the antigen coated onto the microplates), rather than ratios because the ratios are calculated using the negative control as a reference of the cut-off. Therefore, the ratios are affected by changes in the binding of the

146 Negative control to the mutated antigens (Figure 2). To compare cohorts within each variant we used the ratio, 147 because as long as the same antigen is used, normalizing by the negative control enables assessment of the 148 clinical result (positive, borderline, or negative) (Figure 3). 
medRxiv preprint doi: https://doi.org/10.1101/2022.01.10.21268250; this version posted January 11, 2022. The copyright holder for this preprint (which was not certified by peer review) is the author/funder, who has granted medRxiv a license to display the preprint in perpetuity.

149

\section{Results}

\section{Detection of neutralizing antibodies.}

To evaluate the capacity of the RBD variant DBC ELISA kits in this study to detect neutralizing antibodies we compared patient sample results against the Genscript cPass ${ }^{\mathrm{TM}}$ SARS-CoV-2 Neutralization Antibody Kit.

All 168 samples that generated a positive neutralizing antibody result with the GenScript test were also confirmed with the DBC ELISA for $100 \%$ positive agreement (See supplemental Table S5, borderline results are counted as positive). We observed a positive exponential relationship between the inhibition rate produced by the GenScript kit ( $x$ ) and the ratio generated by the ELISA (y), $y=0.4275 e 0.0385 x, r=0.85$ (Figure 1).

Additionally, the GenScript neutralizing antibody kit reported a positive result in $98.2 \%$ (165 of 168) of COVID seroconverters also detected by the DBC ELISA (counting borderline DBS results as negative). The few seropositive samples that produced a negative neutralizing antibody result had a low serological positive ratio $(<1.9)$ relatively close to the Cut-off.

\section{Reactivity of vaccine and infection sera with WT and mutated antigens}

To assess how the humoral immune response in vaccinated individuals compares to antibodies generated from WT infection, and the further influence of the mutations present in the RBD of SARS-CoV-2 variants, we purchased commercial samples of sera from individuals who had received two doses of the Moderna mRNA1273 or the Pfizer BioNTech COVID-19 vaccines during the first 3 months of 2021.

Even though the donors recruited for the study had declared themselves healthy and uninfected with COVID$19,25 \%$ had a positive pre-vaccine anti-SARS-CoV-2 IgG result with the DBC assay (18\% with DiaSorin, Tables S1 and S2 in Supplemental Material). In $80 \%$ of those donors, the ELISA signal was above the maximal $\mathrm{OD}$ of 4 after the first vaccine dose suggesting that the asymptomatic infection might have been equivalent to a first vaccine dose.

For the rest of the vaccinated donors, the ELISA ratio increased more than two times between the first and the second vaccination doses. After the second vaccination dose, binding responses appear to converge, as we no longer observed a higher SARS-CoV-2 IgG ELISA ratio among the subjects who had a viral infection before the vaccination. In fact, only four (including one sample from a donor positive before the vaccination) of 60 samples did not produce a ratio higher than 15 after two vaccination doses (Supplemental Table S1). We, 
medRxiv preprint doi: https://doi.org/10.1101/2022.01.10.21268250; this version posted January 11, 2022. The copyright holder for this preprint (which was not certified by peer review) is the author/funder, who has granted medRxiv a license to display the preprint in perpetuity.

All rights reserved. No reuse allowed without permission.

176 therefore, estimate that a prior infection had a negligible effect in the load of anti-SARS-CoV-2 antibodies after

177 two vaccine doses

178 Sera from vaccinated individuals were compared to sera of three COVID-19 convalescent cohorts: a) ICU 179 patients, split into short (2-7 days) and longer (10+ days) hospitalization, b) a reference panel of samples from 180 SARS-CoV-2 positive donors produced by NIBSC/WHO (WHO), and c) infected ambulatory or hospitalized 181 population (AHP) samples.

182 For AHP and WHO samples, the ELISA OD response of the serological tests in four of the variants was not 183 different $(p>0.05)$ from WT antigen (Figure 2$)$-all four variants had a single mutation in the RBD (N501Y, $184 \mathrm{~L} 452 \mathrm{R}, \mathrm{K} 417 \mathrm{~T}$, or S477N). This pattern was different for the vaccinated, for whom three of the above single 185 mutations and two triple mutation antigens displayed no differences in relation to the WT antigen (Figure 2). No 186 significant differences $(p>0.05)$ were observed between the WT and variants in the reactivity of ICU sera (Figure 187 2). We observed a consistent trend across individual donors (Supplemental Figure S1).

188 Sera from vaccinated individuals consistently exhibited a higher ratio $(p<0.001)$ than sera from infected (but not 189 critically ill) individuals (AHP, WHO) when tested against the WT and each of the 11 variants (Figure 3). Only 190 the vaccinated cohort displayed a median ratio higher than 15 against all the mutated antigens-except the 191 N439K antigen, which significantly lowered the median of ratio results in all cohorts. Still, even against this 192 antigen, none of the samples from vaccinated donors produced a negative ratio result $(<1.0)$. (Figure 3$)$.

193 The second highest antibody response was from critically ill ICU patients who were hospitalized for more than 19410 days. For seven of twelve of the antigens, including the WT antigen, this cohort was not different from the 195 vaccinated. ICU patients upon admission (2-7 days), WHO, and AHP samples presented lower positive ratios 196 (Figure 3).

197 To assess if the differences between the cohorts were due to lower age range of vaccinated and AHP in 198 comparison to ICU patients (Table 1), we split the ratio results of the vaccinated and AHP cohorts into those 199 from donors younger and older than 45 (since the ICU 10+ were all older than 45) and compared them. We 200 found no age-related differences ( $p>>0.05$ ) (Supplemental Figures S2, S3).

\section{Discussion}

202 Differences in cross-variant seroreactivity between population cohorts, including vaccinated individuals and 203 severely ill patients, have been scarcely documented. Current concerns are that some variants might escape 
medRxiv preprint doi: https://doi.org/10.1101/2022.01.10.21268250; this version posted January 11, 2022. The copyright holder for this preprint (which was not certified by peer review) is the author/funder, who has granted medRxiv a license to display the preprint in perpetuity.

All rights reserved. No reuse allowed without permission.

204

205

206

207

208

209

210

211

212

213

214

215

216

217

218

219

220

221

222

223

224

225

226

227

228

229

230

231

232

neutralizing antibodies (an issue just recently developing with the recent multi-mutation bearing variant Omicron), but it is unclear how factors such as vaccines and the severity of the disease can influence the outcome. In this study, we used sera from vaccinated and previously infected individuals to evaluate their ability to recognize mutations in the SARS-CoV-2 RBD. We show that vaccine sera exhibited higher reactivity than convalescence sera from non-critically ill individuals against all twelve studied SARS-CoV-2 RBD antigens tested, including the WT RBD, while the reactivity of critically ill sera bridged those cohorts in most variants.

Understanding the nature of viral and vaccine-induced immunity is critical to managing the course of an epidemic [17]; in particular, how individuals infected early in the pandemic, or those who have been vaccinated will be protected against emerging variants, more importantly, variants holding mutations in the RBD—a region targeted by $\sim 90 \%$ of the neutralizing antibody activity [2].

To establish the capability of the ELISA used in this study to detect neutralizing antibodies we compared its performance against the Genscript cPass SARS-CoV-2 Neutralization antibody detection kit and found $100 \%$ positive agreement. This performance was likely enabled by the fact that the antigen in the ELISA comprises the critical RBD region of the virus. Indeed, immunoassays that use the full spike as antigen show a diminished ability to detect neutralizing antibodies [18].

Having established the capacity of the serological test to detect neutralizing antibodies, we proceeded to evaluate how sera from COVID infected critically ill patients recognize antigens harbouring RBD mutations. Previously, we have shown that IgG levels increase soon after admission to the ICU [16]. Here, we found that sera from ICU patients did not significantly distinguish any of the mutated antigens when compared to WT ( $p>0.05$, Figure 2). Perhaps, severe, and prolonged infection induces a broad polyclonal antibody variability enabling reactivity to a wide range of antigenic variants.

For other cohorts, including the vaccinated, not all the mutations caused a decrease in the antigen's antibody recognition (Figure 2). Vaccine sera did not discriminate five of the variants against the WT according to ELISA OD values, while WHO and AHP samples showed that four of the mutated target antigens, all bearing a single mutation, enabled the same level of antigen recognition in comparison to the WT. Conversely, mutations N439K (present in deemed extinct lineages B1.141 and B1.258), K417N-E484K-N501Y (Beta variant), and L452RT478K (Delta variant) produced lower ODs $(p<0.05)$ than the WT across the vaccinated, WHO and AHP panels. Differences between vaccine sera and WHO or AHP sera might be expected since the antigen configuration and display generated by the mRNA vaccines is dramatically different from that of the live viruses [3]. For 
medRxiv preprint doi: https://doi.org/10.1101/2022.01.10.21268250; this version posted January 11, 2022. The copyright holder for this preprint (which was not certified by peer review) is the author/funder, who has granted medRxiv a license to display the preprint in perpetuity.

All rights reserved. No reuse allowed without permission.

233

234

235

236

237

238

239

240

241

242

243

244

245

246

247

248

249

250

251

252

253

254

255

256

257

258

259

example, K417T-E484K-N501Y (Beta variant) and L452R-E484Q (Delta Plus variant) were distinguished from the WT by WHO and AHP cohorts but not by the vaccinated.

It is noteworthy that the WHO and AHP panels, comprised of samples collected from two separate and unrelated populations, yielded almost identical results (Figure 2). Both panels identified the antigens with mutations corresponding to three VOCs (Beta, Gamma, Delta) Delta Plus, a fact that suggests that variant-specific immunoassay-based screenings on existing sera samples could serve as prospective tests to assess the potential impact of new variants before sufficient epidemiological data is available.

However, we believe that our results do not necessarily extrapolate to patterns in the in vivo neutralization of variants because we are examining antigens constructed solely by the RBD, while the mutations' effect on virus affinity to the ACE2 receptor is not considered here. Nor are we examining the influence of variants' full set of concomitant mutations outside of the RBD. Nevertheless, considering that the RBD plays a critical role in the antigenicity of new variants [2] we hypothesized that a relationship might exist between patient vulnerability to infection and disease and the reactivity of antibodies to isolated variant RBD. This is important considering that in a short time most of the worlds' population should have some degree of immunity either by infection or vaccines' (57\% of the world's population received at least one COVID-19 vaccine dose by December $23^{\text {rd }} 2021$, according to Ourworldindata.org).

Our results tend to match previous findings. Compared to the WT, neutralization of B.1.1.7 (Alpha) and P.1 (Gamma) was found to be roughly equivalent [19], while neutralization of B.1.351 (Beta) spike protein was lower but still relatively robust. Neutralization titers against mutant viruses containing key spike mutations: N501Y and E484K-N501Y-D614G were found to be 1.46 and 0.81 in relation to the WT virus respectively [4] which matches well with the results we obtained for WHO and AHP panels for those mutations (Figure 2). Similarly, Wu et al. [5] detected reductions of the titer of neutralizing antibodies by a factor of 1.2 with pseudo-viruses encoding the B.1.1.7 (Alpha) variant compared to a factor of 6.4 and 3.5 against the B.1.351 (Beta) and P.1 (Gamma) variants. Those studies again align with our data showing that antibody binding to antigen with N501Y mutation alone and WT antigen are the same in all tested cohorts. Conversely, mutants including E484K-N501Y produced lower binding in WHO and AHP samples. Other reports, however, indicate that both B.1.1.7 (Alpha) and B.1.351 (Beta) lead to a decrease in neutralization $[9,14,20]$. 
medRxiv preprint doi: https://doi.org/10.1101/2022.01.10.21268250; this version posted January 11, 2022. The copyright holder for this preprint (which was not certified by peer review) is the author/funder, who has granted medRxiv a license to display the preprint in perpetuity.

All rights reserved. No reuse allowed without permission.

260 Epidemiological data is conflicting but tend to assign higher mortality to mutations associated with B.1.351

261 (Beta) than to B.1.1.7 (Alpha) [21]. However, a recent study found increased transmissibility of variants that

262 included mutations N501Y and E484K but not increased disease severity [22].

263 Residues N501 and E484 play different functions in the infectivity of the virus. Residue N501 is at the RBD-

264 ACE2 interface and mutation N501Y was found to result in an increase of affinity to ACE2 [23]. Mutation E484,

265 in turn, has been identified as an immunodominant spike protein residue with various mutations, including

266 E484K, supporting escape from several monoclonal antibodies [24]. This divergence of functions between

267 residues N501 and E484 might explain why we found E484K to reduce binding of WT-induced antibodies

268 whereas N501Y and WT did not differ.

269 Additionally, in studies with monoclonal antibodies, the spike's B.1.1.7 (Alpha) mutations were shown to reduce

270 neutralization mostly of antibodies specific to the spike's amino-terminal domain (NTD) but only with a small

271 proportion of RBD specific antibodies [25].

272 Considering the immunodominance of the RBD, this could explain some of the moderate reduction in

273 neutralizing activity of convalescence sera against authentic B.1.1.7 (Alpha) or pseudo-viruses carrying the

274 B.1.1.7 (Alpha) spike mutations [26, 27] and the lack of diminished seroreactivity to N501Y by any of the cohorts

275 of this study (Figure 2).

276 Furthermore, neutralization by some RBD-specific and NTD-specific monoclonal antibodies was found to be

277 unaffected by variation in the spike protein suggesting the presence of cross-neutralizing epitopes in both the

278 RBD and NTD [28].

279 Remarkably, mutation N439K produced one of the most consistent drops in ODs compared to WT and other

280 variants (Fig 2). Early in 2021, N439K was the second most prevalent mutation of the RBD sequence [29], but

281 currently is not one of the top ten most distributed mutations worldwide. This mutation is noteworthy because it

282 enhances the binding affinity for the ACE2 receptor and decreases the neutralizing activity of both monoclonal

283 antibodies and serum polyclonal antibodies of convalescence patients [10].

284 However, a deep mutational scanning (DMS) study did not find that mutation N439K significantly alters

285 neutralization by polyclonal antibodies in plasma [30] in contrast to the findings described above [10] and our

286 results (Figs 2 and 3). According to Harvey et al. [31], this discrepancy derives from the fact that the mechanism

287 of immune escape provided by N439K is based on increased affinity to ACE2 rather than by directly affecting 
medRxiv preprint doi: https://doi.org/10.1101/2022.01.10.21268250; this version posted January 11, 2022. The copyright holder for this preprint (which was not certified by peer review) is the author/funder, who has granted medRxiv a license to display the preprint in perpetuity.

All rights reserved. No reuse allowed without permission.

epitope recognition. Perhaps then, the experimental design of the DMS study is less sensitive to detecting immune evasion mutations of this type-an inconsistency that exposes limitations of DMS [32] and highlights the significance of testing the ability of immune (COVID-19 positive) sera to recognize new variants with real human samples and serological-based assays.

Mutation S477N-that has emerged several times during the pandemic [31]—was found in one study to be resistant to neutralization by a panel of monoclonal antibodies, but by contrast, responds similarly to the WT when tested with convalescence (polyclonal) serum [33]—a result that aligns with the data of this study (Figure 2), once again underscoring the advantage of testing real patient sera to evaluate the antigenicity of new mutations.

A recent study found lineage B.1.617.2 (Delta) to be associated with an increase in disease severity [34]. This variant also caused a higher rate of vaccine breakthrough cases ( $17.4 \%$ compared to $5.8 \%$ for all other variants) in Texas, with $8.4 \%$ of all COVID-19 cases occurring in fully vaccinated individuals [35]. In our study, the Delta and kappa variants (which share the L452R mutation) eluded vaccine and infection sera antibodies more than the WT in all cohorts except for critically ill patients (Figure 2).

However, in vaccinated individuals, we observed a shift towards higher ODs when mutation K417N was added to the Delta variant mutations L452R and T478K to replicate the Delta Plus variant (B1.617.3, K41N-L452RT478K) mutation set. These additional mutations diminished the decreased binding seen in the Delta variant compared to Wild Type $(p<0.001)$, which ultimately demonstrated a similar binding profile for the Delta Plus variant vs Wild Type (Figure 2). Not much epidemiology data have been collected so far about the Delta Plus variant, but it has been pointed out that this variant spreads more easily and is potentially more infectious [36].

As the recently emerging Omicron variant begins to spread, it is relevant to this study to note that this VOC bears 5 of the spike protein mutations examined (N501Y, K417N, E484A, T478K, S477N) [37]. While it is beyond the scope of this study to evaluate the effects of these mutations individually or collectively in the immunoreactivity of the Omicron variant, we believe evaluation of this VOC and future inevitable variants using similar assay panels may give insight into immune escape effects.

Our study has some limitations. We have not investigated how antibodies generated by vaccines other than the mRNA based Moderna and Pfizer products would respond to variant antigens; vaccines with different antigen presentations might result in a different pattern of variant recognition. The study is also limited by the fact that 
medRxiv preprint doi: https://doi.org/10.1101/2022.01.10.21268250; this version posted January 11, 2022. The copyright holder for this preprint (which was not certified by peer review) is the author/funder, who has granted medRxiv a license to display the preprint in perpetuity.

All rights reserved. No reuse allowed without permission.

we were not able to examine how immune sera collected several months or years after infection or vaccination

317 would affect recognition of RBD in antigens of new variants.

\section{Conclusions}

In summary, our results indicate that:

a) Recognition of SARS-CoV-2 RBD in the sera of vaccinated individuals is significantly enhanced compared to sera from non-critically infected patients regardless of the antigen variant.

b) The antibodies generated in critically ill individuals are less variant-specific than those of non-critically ill and vaccinated subjects.

c) The antibodies present in the sera of non-critically ill convalescent donors distinguish some variantsnoteworthy, Beta, Gamma, Delta, and Delta Plus variants-in relation to the WT, a fact that could enable variant-specific immunoassay-based screenings to aid evaluating the potential epidemiological impact of new variants.

1. Deng X, Garcia-Knight MA, Khalid MM, Servellita V, Wang C, Morris MK, et al. Transmission, infectivity,

\section{References} and neutralization of a spike L452R SARS-CoV-2 variant. Cell. 2021;184:3426-37 e8.

2. Piccoli L, Park YJ, Tortorici MA, Czudnochowski N, Walls AC, Beltramello M, et al. Mapping Neutralizing and Immunodominant Sites on the SARS-CoV-2 Spike Receptor-Binding Domain by Structure-Guided High-Resolution Serology. Cell. 2020;183:1024-42 e21.

3. Valdes-Balbin Y, Santana-Mederos D, Paquet F, Fernandez S, Climent Y, Chiodo F, et al. Molecular Aspects Concerning the Use of the SARS-CoV-2 Receptor Binding Domain as a Target for Preventive Vaccines. ACS Cent Sci. 2021;7:757-67.

4. Xie X, Liu Y, Liu J, Zhang X, Zou J, Fontes-Garfias CR, et al. Neutralization of SARS-CoV-2 spike 69/70 deletion, E484K and N501Y variants by BNT162b2 vaccine-elicited sera. Nat Med. 2021;27:620-1.

5. Wu K, Werner AP, Koch M, Choi A, Narayanan E, Stewart-Jones GBE, et al. Serum Neutralizing Activity Elicited by mRNA-1273 Vaccine. N Engl J Med. 2021;384:1468-70.

6. Rathnasinghe R, Jangra S, Cupic A, Martínez-Romero C, Mulder L, Kehrer T, et al. The N501Y mutation in SARS-CoV-2 spike leads to morbidity in obese and aged mice and is neutralized by convalescent and post-vaccination human sera. medRxiv : the preprint server for health sciences, 2021. https://doi.org/10.1101/2021.01.19.2124959

7. Edara VV, Hudson WH, Xie X, Ahmed R, Suthar MS. Neutralizing Antibodies Against SARS-CoV-2 Variants After Infection and Vaccination. JAMA. 2021;325:1896-8. 
medRxiv preprint doi: https://doi.org/10.1101/2022.01.10.21268250; this version posted January 11, 2022. The copyright holder for this preprint (which was not certified by peer review) is the author/funder, who has granted medRxiv a license to display the preprint in perpetuity. All rights reserved. No reuse allowed without permission.

8. Chen RE, Zhang X, Case JB, Winkler ES, Liu Y, VanBlargan LA, et al. Resistance of SARS-CoV-2 variants to neutralization by monoclonal and serum-derived polyclonal antibodies. Nat Med. 2021;27:717-26.

9. Wang P, Nair MS, Liu L, Iketani S, Luo Y, Guo Y, et al. Antibody resistance of SARS-CoV-2 variants B.1.351 and B.1.1.7. Nature. 2021;593:130-5.

10. Thomson EC, Rosen LE, Shepherd JG, Spreafico R, da Silva Filipe A, Wojcechowskyj JA, et al. Circulating SARS-CoV-2 spike N439K variants maintain fitness while evading antibody-mediated immunity. Cell. 2021;184:1171-87 e20.

11. Motozono C, Toyoda M, Zahradnik J, Ikeda T, Saito A, Tan TS, et al. An emerging SARS-CoV-2 mutant evading cellular immunity and increasing viral infectivity. bioRxiv. 2021.

12. McCallum M, Bassi J, Marco A, Chen A, Walls AC, lulio JD, et al. SARS-CoV-2 immune evasion by variant B.1.427/B.1.429. bioRxiv. 2021.

13. Hayashi T, Yaegashi N, Konishi I. Effect of RBD (Y453F) mutation in spike glycoprotein of SARS-CoV-2 on neutralizing IgG affinity. medRxiv. 2021.

14. Wang Z, Schmidt F, Weisblum Y, Muecksch F, Barnes CO, Finkin S, et al. mRNA vaccine-elicited antibodies to SARS-CoV-2 and circulating variants. Nature. 2021;592:616-22.

15. Verdecchia P CC, Spanevello A, Angeli F. The pivotal link between ACE2 deficiency and SARS-CoV-2 infection. Eur J Intern Med. 2020;76:14-20.

16. Fraser DD, Cepinskas G, Slessarev M, Martin CM, Daley M, Patel MA, et al. Critically III COVID-19 Patients Exhibit Anti-SARS-CoV-2 Serological Responses. Pathophysiology. 2021;28:212-23.

17. Meschi S, Matusali G, Colavita F, Lapa D, Bordi L, Puro V, et al. Predicting the protective humoral response to a SARS-CoV-2 mRNA vaccine. Clin Chem Lab Med. 2021;59:2010-8.

18. Legros V, Denolly S, Vogrig M, Boson B, Siret E, Rigaill J, et al. A longitudinal study of SARS-CoV-2infected patients reveals a high correlation between neutralizing antibodies and COVID-19 severity. Cell Mol Immunol. 2021;18:318-27.

19. Liu Y, Liu J, Xia H, Zhang X, Fontes-Garfias CR, Swanson KA, et al. Neutralizing Activity of BNT162b2Elicited Serum. N Engl J Med. 2021;384:1466-8.

20. Zhou D, Dejnirattisai W, Supasa P, Liu C, Mentzer AJ, Ginn HM, et al. Evidence of escape of SARS-CoV2 variant B.1.351 from natural and vaccine-induced sera. Cell. 2021;184:2348-61 e6.

21. Davies NG, Jarvis CI, Group CC-W, Edmunds WJ, Jewell NP, Diaz-Ordaz K, et al. Increased mortality in community-tested cases of SARS-CoV-2 lineage B.1.1.7. Nature. 2021;593:270-4.

22. Nagano K, Tani-Sassa C, Iwasaki Y, Takatsuki Y, Yuasa S, Takahashi Y, et al. SARS-CoV-2 R.1 lineage variants that prevailed in Tokyo in March 2021. J Med Virol. 2021;93:6833-6.

23. Starr TN, Greaney AJ, Hilton SK, Ellis D, Crawford KHD, Dingens AS, et al. Deep Mutational Scanning of SARS-CoV-2 Receptor Binding Domain Reveals Constraints on Folding and ACE2 Binding. Cell. 2020;182:1295-310 e20.

24. Weisblum Y, Schmidt F, Zhang F, DaSilva J, Poston D, Lorenzi JC, et al. Escape from neutralizing antibodies by SARS-CoV-2 spike protein variants. Elife. 2020;9.

25. Collier DA, De Marco A, Ferreira I, Meng B, Datir R, Walls AC, et al. SARS-CoV-2 B.1.1.7 sensitivity to mRNA vaccine-elicited, convalescent, and monoclonal antibodies. medRxiv. 2021.

26. Rees-Spear C, Muir L, Griffith SA, Heaney J, Aldon Y, Snitselaar JL, et al. The effect of spike mutations on SARS-CoV-2 neutralization. Cell Rep. 2021;34:108890. 
medRxiv preprint doi: https://doi.org/10.1101/2022.01.10.21268250; this version posted January 11, 2022. The copyright holder for this preprint (which was not certified by peer review) is the author/funder, who has granted medRxiv a license to display the preprint in perpetuity. All rights reserved. No reuse allowed without permission.

27. Hu J, Peng P, Wang K, Fang L, Luo FY, Jin AS, et al. Emerging SARS-CoV-2 variants reduce neutralization sensitivity to convalescent sera and monoclonal antibodies. Cell Mol Immunol. 2021;18:1061-3.

28. Dupont L, Snell LB, Graham C, Seow J, Merrick B, Lechmere T, et al. Neutralizing antibody activity in convalescent sera from infection in humans with SARS-CoV-2 and variants of concern. Nat Microbiol. $2021 ; 6: 1433-42$.

29. Li M, Lou F, Fan H. SARS-CoV-2 variants: a new challenge to convalescent serum and mRNA vaccine neutralization efficiency. Signal Transduct Target Ther. 2021;6:151.

30. Greaney AJ, Loes AN, Crawford KHD, Starr TN, Malone KD, Chu HY, et al. Comprehensive mapping of mutations in the SARS-CoV-2 receptor-binding domain that affect recognition by polyclonal human plasma antibodies. Cell Host Microbe. 2021;29:463-76 e6.

31. Harvey WT, Carabelli AM, Jackson B, Gupta RK, Thomson EC, Harrison EM, et al. SARS-CoV-2 variants, spike mutations and immune escape. Nat Rev Microbiol. 2021;19:409-24.

32. Fowler DM, Fields S. Deep mutational scanning: a new style of protein science. Nat Methods. 2014;11:8017.

33. Liu Z, VanBlargan LA, Bloyet LM, Rothlauf PW, Chen RE, Stumpf S, et al. Identification of SARS-CoV-2 spike mutations that attenuate monoclonal and serum antibody neutralization. Cell Host Microbe. 2021;29:477-88 e4.

34. Ong SWX, Chiew CJ, Ang LW, Mak TM, Cui L, Toh M, et al. Clinical and virological features of SARSCoV-2 variants of concern: a retrospective cohort study comparing B.1.1.7 (Alpha), B.1.315 (Beta), and B.1.617.2 (Delta). Clin Infect Dis. 2021;23:ciab721.

35. Musser JM, Christensen PA, Olsen RJ, Long SW, Subedi S, Davis JJ, et al. Delta variants of SARS-CoV2 cause significantly increased vaccine breakthrough COVID-19 cases in Houston, Texas. medRxiv. 2021.

36. Roy B, Roy H. The Delta Plus variant of COVID-19: Will it be the worst nightmare in the SARS-CoV-2 pandemic? Journal of Biomedical Sciences. 2021;8:1-2.

37. Cele S, Jackson L, Khan K, et al. SARS-CoV-2 Omicron has extensive but incomplete escape of Pfizer BNT162b2 elicited neutralization and requires ACE2 for infection. Preprint. medRxiv. 2021;2021.12.08.21267417. Published 2021 Dec 11. doi:10.1101/2021.12.08.21267417 


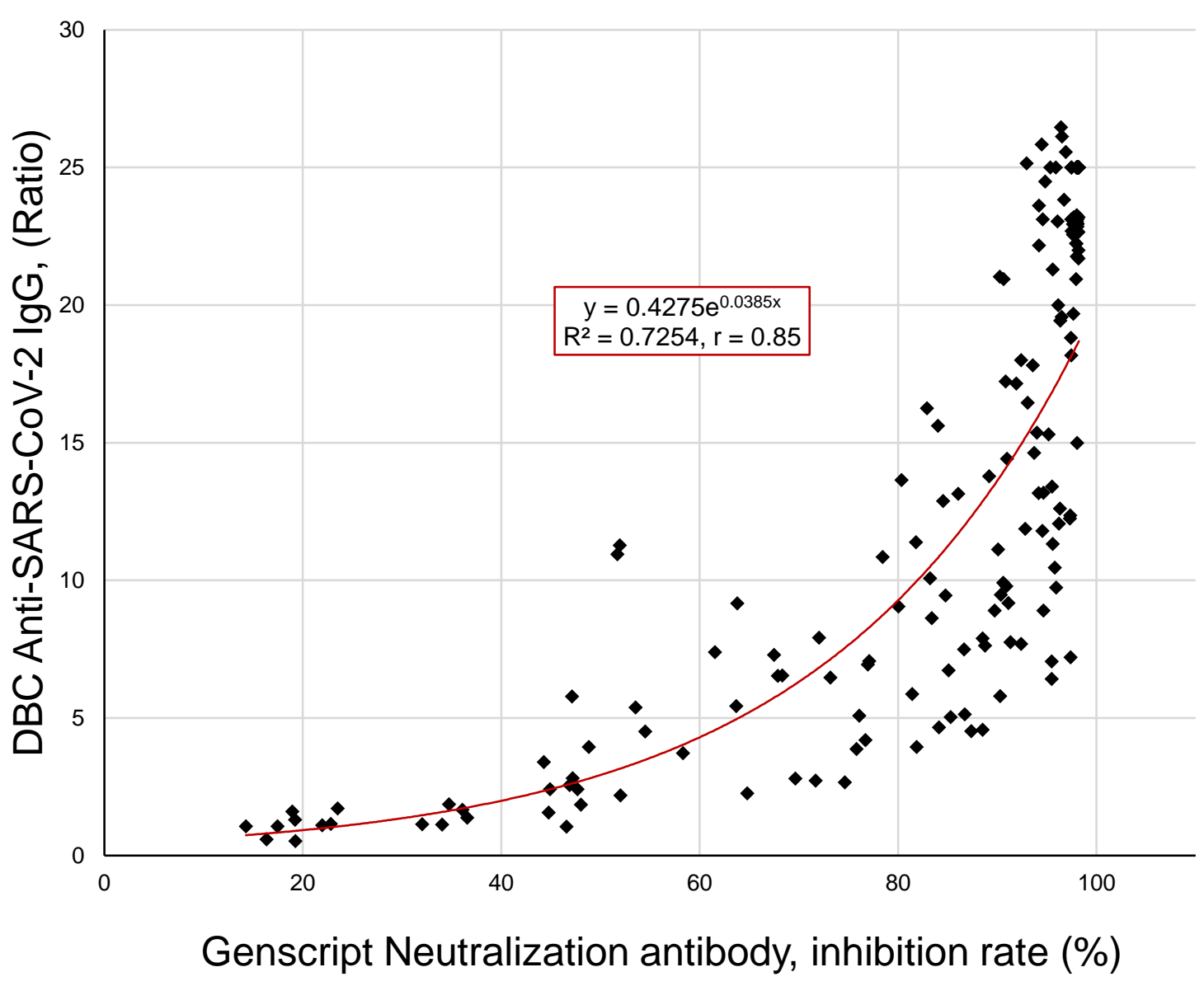

Fig 1. Relationship between neutralization and IgG antibody ratio as determined by the Genscript cPass $^{\text {TM }}$ SARS-CoV-2 Neutralization Antibody Detection/Surrogate Virus Neutralization Test Kit (L00847) and DBC's Health Canada authorized anti-SARS-CoV-2 IgG (CAN-IGG-19). Ratio (DBC kit) was calculated based on a Cut Off [Cut-Off $(\mathrm{CO})=$ (Mean of 3 Negative Controls) $\times$ factor 1.5] which is then used to generate a ratio [Ratio $=$ OD of sample / Cut-Off]. 
medRxiv preprint doi: https://doi.org/10.1101/2022.01.10.21268250; this version posted January 11, 2022. The copyright holder for this preprint (which was not certified by peer review) is the author/funder, who has granted medRxiv a license to display the preprint in perpetuity. All rights reserved. No reuse allowed without permission.

\begin{tabular}{|c|c|c|c|c|c|c|c|}
\hline $\mathbf{A}$ & Vacc & & & $\mathbf{B}$ & 0 Days & & \\
\hline RBD Mutation & Shift & p-value & & RBD Mutation & Shift & p-value & \\
\hline$\overline{\mathrm{N} 501 \mathrm{Y}}$ & & 0.6252 & NS & $\overline{N 501 Y}$ & & 0.3648 & NS \\
\hline K417N, L452R, T478K & & 0.9917 & NS & K417N, L452R, T478K & & 0.2645 & NS \\
\hline K417T, E484K, N501Y & & 0.8831 & NS & K417T, E484K, N501Y & & 0.5962 & NS \\
\hline S477N & & 0.1944 & NS & S477N & & 0.9977 & NS \\
\hline L452R & & 0.0709 & NS & L452R & & 0.5594 & NS \\
\hline K417T & & 0.0087 & $* *$ & K417T & & 0.5595 & NS \\
\hline K417N, E484K, N501Y & & 0.0058 & $* *$ & K417N, E484K, N501Y & & 0.5325 & NS \\
\hline L452R, T478K & & 0.0009 & $* * *$ & L452R, T478K & & 1.0000 & NS \\
\hline Y453F & & 0.0020 & $\star \star$ & Y453F & & 0.9344 & NS \\
\hline N439K & & $<0.0001$ & $* * *$ & $\mathrm{~N} 439 \mathrm{~K}$ & & 0.9613 & NS \\
\hline L452R, E484Q & & $<0.0001$ & *** & L452R, E484Q & & 0.9079 & NS \\
\hline
\end{tabular}

C

2-7 Days Post ICU

D

\begin{tabular}{|c|c|c|c|}
\hline RBD Mutation & Shift & p-valt & \\
\hline N501Y & & 0.9792 & NS \\
\hline K417N, L452R, T478K & & 0.0109 & * \\
\hline K417T, E484K, N501Y & & 0.0004 & *** \\
\hline S477N & & 0.4540 & NS \\
\hline L452R & & 0.5529 & NS \\
\hline K417T & & 0.7579 & NS \\
\hline K417N, E484K, N501Y & & 0.0011 & ** \\
\hline L452R, T478K & & 0.0114 & * \\
\hline Y453 & & 0.0201 & * \\
\hline N439K & & 0.0180 & * \\
\hline L452R, E484Q & & 0.0026 & ** \\
\hline
\end{tabular}

$\mathbf{E}$ AHP

\begin{tabular}{|c|c|c|c|}
\hline RBD Mutation & Shift & \multicolumn{2}{|c|}{ p-value } \\
\hline$\overline{\mathrm{N} 501 \mathrm{Y}}$ & & 0.8659 & NS \\
\hline K417N, L452R, T478K & & 0.0117 & * \\
\hline K417T, E484K, N501Y & & 0.0028 & ** \\
\hline S477N & & 0.3526 & NS \\
\hline L452R & & 0.4757 & NS \\
\hline K417T & & 0.8380 & NS \\
\hline K417N, E484K, N501Y & & 0.0013 & ** \\
\hline L452R, T478K & & 0.0149 & * \\
\hline Y453F & & 0.0292 & * \\
\hline N439K & & 0.0048 & ** \\
\hline L452R, E484Q & & 0.0015 & ** \\
\hline
\end{tabular}

Figure 2. Comparative evaluation of antibody recognition of mutated antigens against WT in five cohorts by optical density (OD). The OD, rather than the ratio, was used to prevent bias from differences in the ELISAs' negative control OD between antigens. Univariate Steel pairwise ranking non-parametric comparisons against the WT antigen. Experimental datasets for cohorts (A) Vaccinated, (B) >10 days post ICU admission, (C) $\mathrm{P}<0.05 ;\left(^{* *}\right) \mathrm{P}<0.01,\left({ }^{* * *}\right) \mathrm{P}<0.001$. 
medRxiv preprint doi: https://doi.org/10.1101/2022.01.10.21268250; this version posted January 11, 2022. The copyright holder for this preprint (which was not certified by peer review) is the author/funder, who has granted medRxiv a license to display the preprint in perpetuity. All rights reserved. No reuse allowed without permission.

$447 \quad$ Figure 3.

448

449

450

451

452

453

454

455

456

457

458

459

460

461

462

463

464

465

466

467

468

469

470

471

472

473

474

475

476

477

478

\section{A}



C

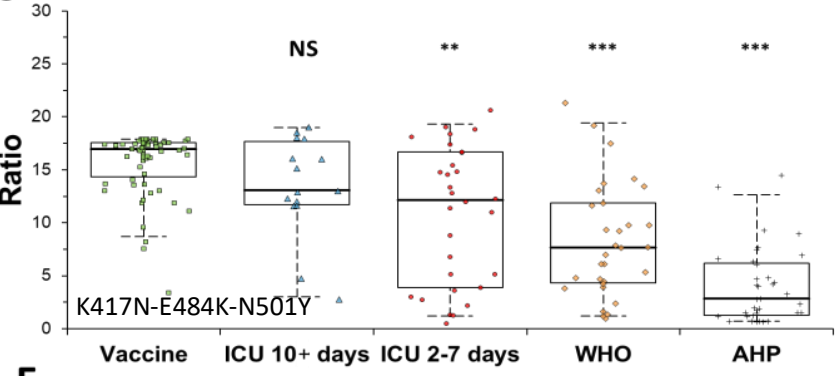

E
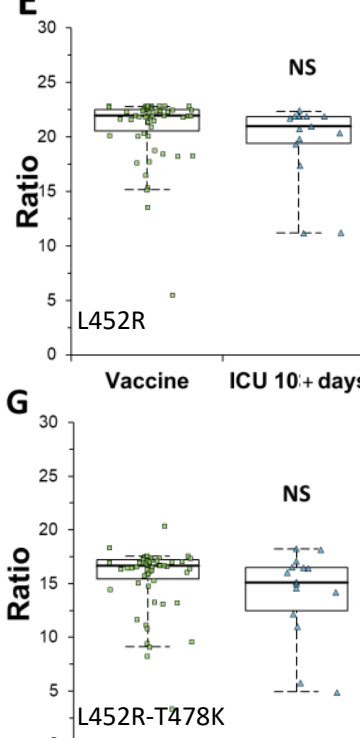

L452R-T478K
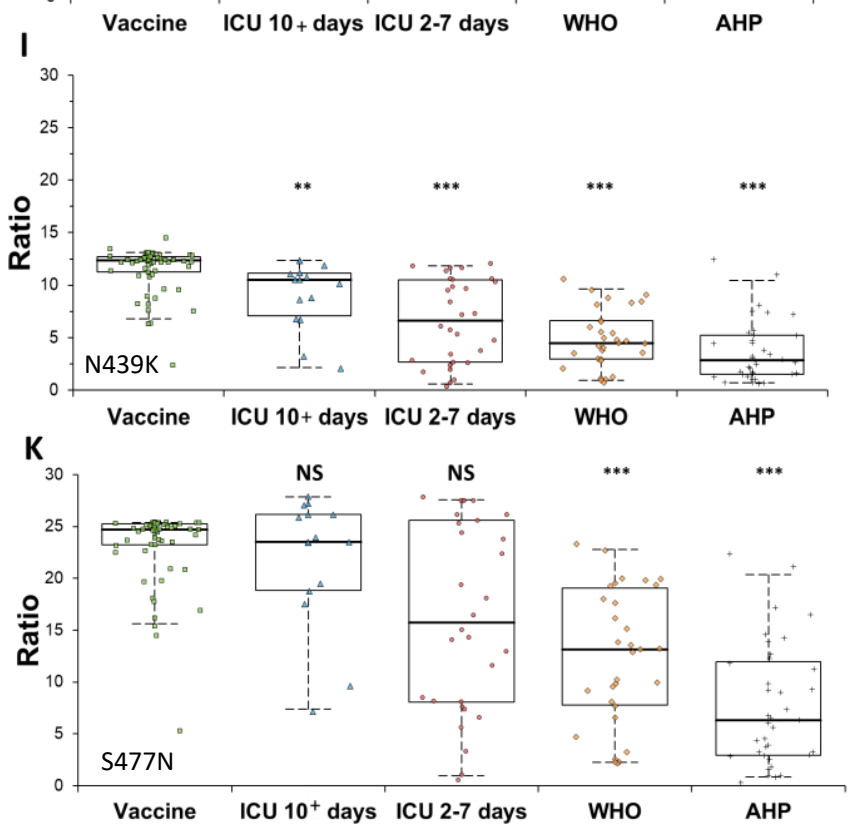
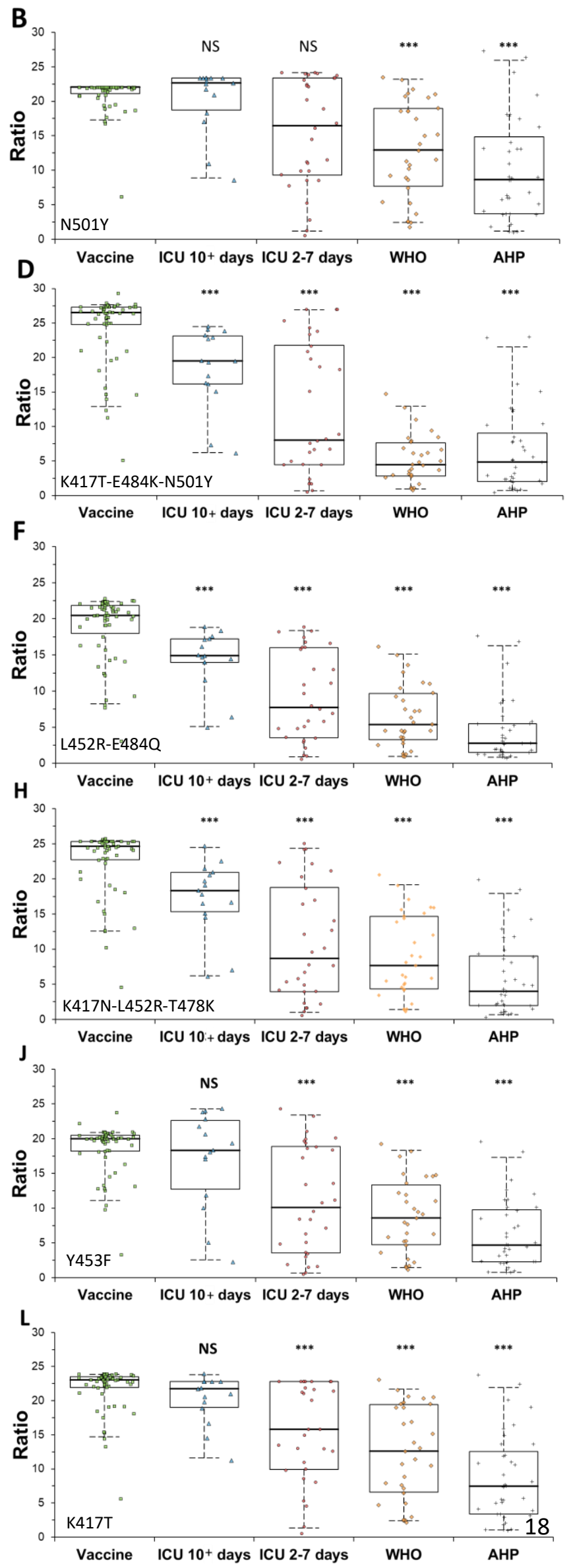
medRxiv preprint doi: https://doi.org/10.1101/2022.01.10.21268250; this version posted January 11, 2022. The copyright holder for this preprint (which was not certified by peer review) is the author/funder, who has granted medRxiv a license to display the preprint in perpetuity.

All rights reserved. No reuse allowed without permission.

479 Figure 3. Reactivity of sera from vaccinated individuals (Vaccine), from patients 2-7 (ICU 2-7 days) and

480 more than 10 days (ICU 10+ days) after admission to ICU, from a NIBSC/World Health Organization

481 (WHO) panel, and from ambulatory and hospitalized population (AHP) to recombinant antigens

482 comprising the RBD of wild type (WT) SARS-CoV-2 or recombinant antigens with mutations present in

483 variants of the virus. Ratio was calculated based on a Cut Off [Cut-Off $(\mathrm{CO})=$ (Mean of 3 Negative

484 Controls) $x$ factor 2.0] which is then used to generate a ratio [Ratio $=$ OD of sample / Cut-Off]. The cohorts

485 were compared against the vaccinated using Steel pairwise ranking non-parametric method: (NS)

486 nonsignificant, $\left({ }^{*}\right) \mathrm{P}<0.05 ;\left(^{* *}\right) \mathrm{P}<0.01,\left(^{* *}\right) \mathrm{P}<0.001$. The median is plotted as a line. The box represents $1^{\text {st }}$

487 to $3^{\text {rd }}$ quartiles and the whiskers the minimum and maximum of the $95 \%$ confidence interval. (A) WT, (B)

488 N501Y, (C) K417N-E484K-N501Y, (D) K417T-E484K-N501Y, (E) L452R, (F) L452R-E484Q, (G) L452R-

489 T478K, (H) K417N-L452R-T478K, (I) N439K, (J) Y453F, (K) S477N, (L) K417T.

490

491

492

493

494 
medRxiv preprint doi: https://doi.org/10.1101/2022.01.10.21268250; this version posted January $11,2022$. The copyright holder for this preprint (which was not certified by peer review) is the author/funder, who has granted medRxiv a license to display the preprint in perpetuity.

All rights reserved. No reuse allowed without permission.

SUPPLEMENTAL MATERIAL

496 Table S1. Analysis of samples from the Moderna COVID-19 Vaccine Serum Panel

\begin{tabular}{|c|c|c|c|c|c|c|c|}
\hline \multirow{2}{*}{\multicolumn{2}{|c|}{\begin{tabular}{l|l} 
Negative & Borderline \\
Manufacturer: & \\
\end{tabular}}} & \multicolumn{6}{|l|}{ Positive } \\
\hline & & \multicolumn{3}{|l|}{ DiaSorin } & \multicolumn{3}{|l|}{ DBC } \\
\hline \multicolumn{2}{|l|}{ Device: } & \multicolumn{3}{|c|}{ LIAISON SARS-CoV-2 S1/S2 IgG } & \multicolumn{3}{|c|}{$\begin{array}{l}\text { Anti-SARS-CoV-2 IgG } \\
\text { (CAN-IGG-19) }\end{array}$} \\
\hline \multicolumn{2}{|c|}{ Device Interpretation: } & \multicolumn{3}{|c|}{$\mathrm{AU} / \mathrm{mL} ;<15$ negative, $\geq 15$ positive } & \multicolumn{3}{|c|}{$\begin{array}{c}\text { Ratio; } \leq 1.0 \text { negative, } \geq 1.2 \\
\text { positive, }>1.0 \text { and }<1.2 \text { borderline }\end{array}$} \\
\hline Count & Sample ID & $\begin{array}{c}\text { Pre- } \\
\text { Vaccine }\end{array}$ & $\begin{array}{l}\text { Post-Vaccine } \\
1^{\text {st }} \text { Dose }\end{array}$ & $\begin{array}{l}\text { Post- } \\
\text { Vaccine } \\
2^{\text {nd }} \text { Dose }\end{array}$ & $\begin{array}{c}\text { Pre- } \\
\text { Vaccine }\end{array}$ & $\begin{array}{l}\text { Post- } \\
\text { Vaccine } \\
1^{\text {st }} \\
\text { Dose }\end{array}$ & $\begin{array}{l}\text { Post- } \\
{\text { Vaccine } 2^{\text {nd }}}^{\text {Dose }}\end{array}$ \\
\hline 1 & 101 & $<3$ & 117 & 3,380 & 0.65 & 10.97 & $>25$ \\
\hline 2 & 102 & 60 & 27200 & 17,920 & 3.32 & $>25$ & $>25$ \\
\hline 3 & 103 & 17.5 & 5400 & 4,280 & 0.78 & $>25$ & $>25$ \\
\hline 4 & 104 & 882 & 4080 & 3,692 & 16.2 & $>25$ & $>25$ \\
\hline 5 & 105 & $<3.80$ & 172 & 1,150 & 0.65 & 15.6 & $>25$ \\
\hline 6 & 106 & $<3.80$ & 189 & 4,760 & 0.54 & 17.12 & $>25$ \\
\hline 7 & 107 & $<3.80$ & 100 & 880 & 0.73 & 8.9 & 20.06 \\
\hline 8 & 108 & 8.1 & 256 & 1,580 & 2.16 & $>25$ & $>25$ \\
\hline 9 & 109 & $<3$ & 74 & 2,340 & 0.7 & 6.41 & $>25$ \\
\hline 10 & 110 & $<3$ & 249 & 4,680 & 0.56 & 19 & $>25$ \\
\hline 11 & 111 & $<3.80$ & 78 & 363 & 0.6 & 9.97 & 18.9 \\
\hline 12 & 112 & $<3.80$ & 172 & 4,340 & 0.65 & 15.06 & $>25$ \\
\hline 13 & 113 & $<3$ & 229 & 2,420 & 0.63 & 15.8 & $>25$ \\
\hline 14 & 115 & 19.7 & 6360 & 12,160 & 1.55 & $>25$ & $>25$ \\
\hline 15 & 117 & $<3.80$ & 303 & 3,400 & 1.01 & 17.03 & $>25$ \\
\hline 16 & 118 & $<3.80$ & 30 & 1,020 & 0.63 & 2.13 & 17.81 \\
\hline 17 & 119 & 39.6 & 2420 & 5,600 & 4.07 & $>25$ & $>25$ \\
\hline 18 & 120 & $<3$ & 65 & 1,080 & 0.72 & 5.65 & $>25$ \\
\hline 19 & 121 & $<3$ & 111 & 2,920 & 0.57 & 10.06 & $>25$ \\
\hline 20 & 122 & $<3$ & 117 & 3,660 & 0.58 & 10.86 & $>25$ \\
\hline 21 & 123 & $<3$ & 49 & 2,200 & 0.54 & 3.63 & $>25$ \\
\hline 22 & 124 & 14.1 & 115 & 1,884 & 0.74 & 12.61 & $>25$ \\
\hline 23 & 126 & $<3.80$ & 128 & 1,360 & 0.7 & 12.3 & $>25$ \\
\hline 24 & 127 & $<3$ & 103 & 1,360 & 0.59 & 6.77 & 20.5 \\
\hline 25 & 128 & $<3$ & 128 & 2,120 & 0.55 & 8.64 & $>25$ \\
\hline 26 & 129 & $<3$ & 169 & 1,640 & 0.54 & 15.72 & $>25$ \\
\hline 27 & 130 & $<3.80$ & 127 & 2,600 & 0.92 & 14.08 & $>25$ \\
\hline 28 & 132 & $<3.80$ & 173 & 4,160 & 0.87 & 16.49 & $>25$ \\
\hline 29 & 133 & $<3$ & 193 & 2,320 & 0.61 & 16.68 & $>25$ \\
\hline
\end{tabular}


medRxiv preprint doi: https://doi.org/10.1101/2022.01.10.21268250; this version posted January 11, 2022. The copyright holder for this preprint (which was not certified by peer review) is the author/funder, who has granted medRxiv a license to display the preprint in perpetuity.

All rights reserved. No reuse allowed without permission.

\begin{tabular}{|l|c|c|c|c|c|c|c|}
\cline { 7 - 8 } 30 & 134 & $<3$ & 9 & 2,460 & 0.66 & 0.93 & $>25$ \\
\hline 31 & 135 & $<3$ & 11 & 1,970 & 0.7 & 1.81 & $>25$ \\
\hline 32 & 136 & $<3$ & 91 & 2,180 & 0.59 & 6.1 & $>25$ \\
\hline 33 & 137 & $<3$ & 238 & 4,720 & 0.62 & 17.96 & $>25$ \\
\hline 34 & 138 & $<3$ & 6 & 143 & 0.7 & 0.94 & 15.4 \\
\hline 35 & 141 & $<3$ & 79 & 1,440 & 0.75 & 7.22 & $>25$ \\
\hline 36 & 144 & 368 & 16800 & 17,920 & 20.64 & $>25$ & $>25$ \\
\hline 37 & 145 & 86.4 & 14000 & 9,600 & 4.82 & $>25$ & $>25$ \\
\hline 38 & 146 & $<3$ & 40 & 253 & 0.55 & 2.5 & 16.7 \\
\hline 39 & 150 & 58.2 & 3180 & 4,400 & 6.92 & $>25$ & $>25$ \\
\hline 40 & 155 & $<3.80$ & 10 & 208 & 0.64 & 1.65 & 15.92 \\
\hline 41 & 156 & $<3$ & $<3.00$ & 176 & 0.62 & 0.65 & 14.9 \\
\hline 42 & 157 & $<3$ & 28 & 388 & 0.67 & 2.35 & $>25$ \\
\hline 43 & 158 & $<3.80$ & $<3.80$ & 145 & 2.98 & 3.16 & 14 \\
\hline 44 & 159 & $<3$ & $<3.00$ & 180 & 0.74 & 1.07 & 13.5 \\
\hline 45 & 160 & $<3$ & 116972 & $1,321,064$ & 0.48 & 4.21 & $>25$ \\
\hline
\end{tabular}

498

499

500

501

502

503

504

505

506

507

508

509

510

511

512

513

514

515

516

517 
medRxiv preprint doi: https://doi.org/10.1101/2022.01.10.21268250; this version posted January 11, 2022. The copyright holder for this preprint (which was not certified by peer review) is the author/funder, who has granted medRxiv a license to display the preprint in perpetuity.

All rights reserved. No reuse allowed without permission.

518 Table S2. Analysis of samples from the Pfizer COVID-19 Vaccine Serum Panel.

\begin{tabular}{|c|c|c|c|c|c|c|c|}
\hline Negative & \multicolumn{2}{|c|}{ Borderline } & Positive & & & & \\
\hline \multicolumn{2}{|c|}{ Manufacturer: } & \multicolumn{3}{|l|}{ DiaSorin } & \multicolumn{3}{|l|}{ DBC } \\
\hline \multicolumn{2}{|l|}{ Device: } & \multicolumn{3}{|c|}{ LIAISON SARS-CoV-2 S1/S2 IgG } & \multicolumn{3}{|c|}{$\begin{array}{l}\text { Anti-SARS-CoV-2 IgG } \\
\text { (CAN-IGG-19) }\end{array}$} \\
\hline \multicolumn{2}{|c|}{$\begin{array}{l}\text { Device } \\
\text { Interpretation: }\end{array}$} & \multicolumn{3}{|c|}{$\mathrm{AU} / \mathrm{mL} ;<15$ negative, $\geq 15$ positive } & \multicolumn{3}{|c|}{$\begin{array}{c}\text { Ratio; } \leq 1.0 \text { negative, } \geq 1.2 \text { positive, }>1.0 \\
\text { and }<1.2 \text { borderline }\end{array}$} \\
\hline Count & $\begin{array}{l}\text { Sample } \\
\text { ID }\end{array}$ & $\begin{array}{l}\text { Pre- } \\
\text { Vaccine }\end{array}$ & $\begin{array}{l}\text { Post- } \\
\text { Vaccine } \\
\text { 1st Dose }\end{array}$ & $\begin{array}{l}\text { Post- } \\
\text { Vaccine } \\
\text { 2nd Dose }\end{array}$ & $\begin{array}{l}\text { Pre- } \\
\text { Vaccine }\end{array}$ & $\begin{array}{l}\text { Post- } \\
\text { Vaccine 1st } \\
\text { Dose }\end{array}$ & $\begin{array}{l}\text { Post-Vaccine } \\
\text { 2nd Dose }\end{array}$ \\
\hline 1 & 114 & 117 & 5,200 & 4,880 & 6.85 & $>25$ & $>25$ \\
\hline 2 & 116 & 11.1 & 127 & 1,120 & 2.48 & 15.47 & 18.2 \\
\hline 3 & 125 & 131 & 1,430 & 1,090 & 16.87 & $>25$ & 18.1 \\
\hline 4 & 131 & $<3.80$ & 81 & 1,350 & 0.76 & 7.84 & $>25$ \\
\hline 5 & 139 & $<3.80$ & 23 & 169 & 1.39 & 3.53 & 14.02 \\
\hline 6 & 140 & $<3.80$ & 98 & 50 & 0.74 & 9.89 & 4.82 \\
\hline 7 & 142 & $<3.80$ & 7 & 2,920 & 0.72 & 1.51 & $>25$ \\
\hline 8 & 143 & $<3.80$ & 36 & 2,150 & 0.62 & 2.63 & $>25$ \\
\hline 9 & 147 & $<3.80$ & 25 & 226 & 0.5 & 1.95 & 16.7 \\
\hline 10 & 148 & $<3.80$ & 102 & 4,080 & 0.58 & 9.16 & $>25$ \\
\hline 11 & 149 & $<3.80$ & 25 & 2,070 & 0.84 & 1.91 & $>25$ \\
\hline 12 & 151 & $<3.80$ & 34 & 1,640 & 0.7 & 3.58 & $>25$ \\
\hline 13 & 152 & 12.8 & 3,468 & 4,280 & 1.61 & $>25$ & $>25$ \\
\hline 14 & 153 & $<3.80$ & 33 & 261 & 0.53 & 4.21 & 18.54 \\
\hline 15 & 154 & 100 & 7,760 & 8,240 & 6.63 & $>25$ & $>25$ \\
\hline
\end{tabular}


medRxiv preprint doi: https://doi.org/10.1101/2022.01.10.21268250; this version posted January 11, 2022. The copyright holder for this preprint (which was not certified by peer review) is the author/funder, who has granted medRxiv a license to display the preprint in perpetuity. All rights reserved. No reuse allowed without permission.

Table S3. Age and sex of sample donor in the 4 Cohorts

\begin{tabular}{|c|c|c|}
\hline Vaccinated & & \\
\hline Sample \# & Age & Sex \\
\hline 101 & $<20$ & $M$ \\
\hline 102 & $21-30$ & $\mathrm{~F}$ \\
\hline 103 & $21-30$ & $\mathrm{~F}$ \\
\hline 104 & $21-30$ & $\mathrm{~F}$ \\
\hline 105 & $21-30$ & $M$ \\
\hline 106 & $21-30$ & $M$ \\
\hline 107 & $31-40$ & $\mathrm{~F}$ \\
\hline 108 & $31-40$ & $\mathrm{~F}$ \\
\hline 109 & $31-40$ & $\mathrm{~F}$ \\
\hline 110 & $31-40$ & $\mathrm{~F}$ \\
\hline 111 & $31-40$ & $\mathrm{~F}$ \\
\hline 112 & $31-40$ & $\mathrm{~F}$ \\
\hline 113 & $31-40$ & $\mathrm{~F}$ \\
\hline 114 & $31-40$ & $\mathrm{~F}$ \\
\hline 115 & $31-40$ & $M$ \\
\hline 116 & $31-40$ & $M$ \\
\hline 117 & $41-50$ & $\mathrm{~F}$ \\
\hline 118 & $41-50$ & $\mathrm{~F}$ \\
\hline 119 & $41-50$ & $\mathrm{~F}$ \\
\hline 120 & $41-50$ & $\bar{F}$ \\
\hline 121 & $41-50$ & $\bar{F}$ \\
\hline 122 & $41-50$ & $\mathrm{~F}$ \\
\hline 123 & $41-50$ & $\mathrm{~F}$ \\
\hline 124 & $41-50$ & $\bar{F}$ \\
\hline 125 & $41-50$ & $\mathrm{~F}$ \\
\hline 126 & $41-50$ & $M$ \\
\hline 127 & $41-50$ & $M$ \\
\hline 128 & $41-50$ & $M$ \\
\hline 129 & $41-50$ & $M$ \\
\hline 130 & $41-50$ & $M$ \\
\hline 131 & $41-50$ & $M$ \\
\hline 132 & $51-60$ & $\mathrm{~F}$ \\
\hline 133 & $51-60$ & $\mathrm{~F}$ \\
\hline 134 & $51-60$ & $\bar{F}$ \\
\hline 135 & $51-60$ & $\mathrm{~F}$ \\
\hline 136 & $51-60$ & $\mathrm{~F}$ \\
\hline 137 & $51-60$ & $\mathrm{~F}$ \\
\hline 138 & $51-60$ & $\mathrm{~F}$ \\
\hline
\end{tabular}


medRxiv preprint doi: https://doi.org/10.1101/2022.01.10.21268250; this version posted January 11, 2022. The copyright holder for this preprint (which was not certified by peer review) is the author/funder, who has granted medRxiv a license to display the preprint in perpetuity. All rights reserved. No reuse allowed without permission.

\begin{tabular}{|c|c|c|}
\hline 139 & $51-60$ & $\mathrm{~F}$ \\
\hline 140 & $51-60$ & $F$ \\
\hline 141 & $51-60$ & $M$ \\
\hline 142 & $51-60$ & M \\
\hline 143 & $51-60$ & $M$ \\
\hline 144 & $61-70$ & $\mathrm{~F}$ \\
\hline 145 & $61-70$ & $\mathrm{~F}$ \\
\hline 146 & $61-70$ & $F$ \\
\hline 147 & $61-70$ & $\mathrm{~F}$ \\
\hline 148 & $61-70$ & $\mathrm{~F}$ \\
\hline 149 & $61-70$ & $F$ \\
\hline 150 & $61-70$ & M \\
\hline 151 & $61-70$ & $\mathrm{M}$ \\
\hline 152 & $61-70$ & $M$ \\
\hline 153 & $61-70$ & $M$ \\
\hline 154 & $61-70$ & $M$ \\
\hline 155 & $71-80$ & $\mathrm{~F}$ \\
\hline 156 & $71-80$ & $\mathrm{~F}$ \\
\hline 157 & $71-80$ & $F$ \\
\hline 158 & $71-80$ & $M$ \\
\hline 159 & $71-80$ & $M$ \\
\hline 160 & $71-80$ & $M$ \\
\hline AVE & 50.1 & \\
\hline Median & 49.5 & \\
\hline SD & 14.8 & \\
\hline Females & & 38 \\
\hline Males & & 22 \\
\hline
\end{tabular}

523

\begin{tabular}{|c|l|l|}
\hline AHP & & \\
\hline Sample \# & Age & Sex \\
\hline 161 & $21-30$ & F \\
\hline 162 & $21-30$ & F \\
\hline 163 & $21-30$ & F \\
\hline 164 & $21-30$ & F \\
\hline 165 & $21-30$ & M \\
\hline 166 & $31-40$ & F \\
\hline 167 & $31-40$ & F \\
\hline 168 & $31-40$ & F \\
\hline 169 & $31-40$ & F \\
\hline 170 & $31-40$ & F \\
\hline 171 & $31-40$ & F \\
\hline
\end{tabular}


medRxiv preprint doi: https://doi.org/10.1101/2022.01.10.21268250; this version posted January 11, 2022. The copyright holder for this preprint (which was not certified by peer review) is the author/funder, who has granted medRxiv a license to display the preprint in perpetuity. All rights reserved. No reuse allowed without permission.

\begin{tabular}{|c|c|c|}
\hline 172 & $31-40$ & M \\
\hline 173 & $31-40$ & $\mathrm{M}$ \\
\hline 174 & $41-50$ & $\mathrm{~F}$ \\
\hline 175 & $41-50$ & $\mathrm{~F}$ \\
\hline 176 & $41-50$ & $\mathrm{~F}$ \\
\hline 177 & $41-50$ & $\mathrm{~F}$ \\
\hline 178 & $41-50$ & $\mathrm{~F}$ \\
\hline 179 & $41-50$ & $\mathrm{~F}$ \\
\hline 180 & $41-50$ & $\mathrm{M}$ \\
\hline 181 & $41-50$ & $\mathrm{M}$ \\
\hline 182 & $51-60$ & $\mathrm{~F}$ \\
\hline 183 & $51-60$ & $\mathrm{~F}$ \\
\hline 184 & $51-60$ & $\mathrm{~F}$ \\
\hline 185 & $51-60$ & $\mathrm{~F}$ \\
\hline 186 & $51-60$ & $\mathrm{~F}$ \\
\hline 187 & $51-60$ & $\mathrm{~F}$ \\
\hline 188 & $51-60$ & $\mathrm{~F}$ \\
\hline 189 & $51-60$ & $\mathrm{~F}$ \\
\hline 190 & $51-60$ & $\mathrm{M}$ \\
\hline 191 & $51-60$ & $M$ \\
\hline 192 & $51-60$ & $\mathrm{M}$ \\
\hline 193 & $51-60$ & $\mathrm{M}$ \\
\hline 194 & $61-70$ & $\mathrm{~F}$ \\
\hline 195 & $61-70$ & $\mathrm{~F}$ \\
\hline 196 & $71-80$ & $\mathrm{~F}$ \\
\hline 197 & $81-90$ & $\mathrm{~F}$ \\
\hline AVE & 46.9 & \\
\hline Median & 47 & \\
\hline SD & 13.5 & \\
\hline Females & & 28 \\
\hline Males & & 9 \\
\hline
\end{tabular}

524

\begin{tabular}{|c|l|l|l|}
\hline ICU 2 - 7 days & & & \\
\hline Sample \# & Age & Sex & Outcome \\
\hline 198 & $31-40$ & $\mathrm{M}$ & ALIVE \\
\hline 199 & $41-50$ & $\mathrm{~F}$ & ALIVE \\
\hline 200 & $41-50$ & $\mathrm{M}$ & ALIVE \\
\hline 201 & $41-50$ & $\mathrm{M}$ & ALIVE \\
\hline 202 & $41-50$ & $\mathrm{M}$ & DEAD \\
\hline 203 & $41-50$ & $\mathrm{M}$ & ALIVE \\
\hline 204 & $51-60$ & $\mathrm{~F}$ & ALIVE \\
\hline
\end{tabular}


medRxiv preprint doi: https://doi.org/10.1101/2022.01.10.21268250; this version posted January 11, 2022. The copyright holder for this preprint (which was not certified by peer review) is the author/funder, who has granted medRxiv a license to display the preprint in perpetuity. All rights reserved. No reuse allowed without permission.

\begin{tabular}{|c|c|c|c|}
\hline 205 & $51-60$ & $\mathrm{~F}$ & ALIVE \\
\hline 206 & $51-60$ & $\mathrm{~F}$ & ALIVE \\
\hline 207 & $51-60$ & $\mathrm{~F}$ & ALIVE \\
\hline 208 & $51-60$ & $M$ & ALIVE \\
\hline 209 & $51-60$ & $M$ & ALIVE \\
\hline 210 & $51-60$ & $M$ & ALIVE \\
\hline 211 & $51-60$ & $M$ & ALIVE \\
\hline 212 & $51-60$ & M & ALIVE \\
\hline 213 & $61-70$ & $\mathrm{~F}$ & ALIVE \\
\hline 214 & $61-70$ & $F$ & ALIVE \\
\hline 215 & $61-70$ & $F$ & ALIVE \\
\hline 216 & $61-70$ & $F$ & ALIVE \\
\hline 217 & $61-70$ & $\mathrm{~F}$ & ALIVE \\
\hline 218 & $61-70$ & $M$ & ALIVE \\
\hline 219 & $61-70$ & $M$ & ALIVE \\
\hline 220 & $61-70$ & $M$ & ALIVE \\
\hline 221 & $61-70$ & $M$ & ALIVE \\
\hline 222 & $71-80$ & $\mathrm{~F}$ & ALIVE \\
\hline 223 & $71-80$ & $\mathrm{M}$ & DEAD \\
\hline 224 & $71-80$ & $M$ & ALIVE \\
\hline 225 & $71-80$ & $M$ & ALIVE \\
\hline 226 & $81-90$ & $\mathrm{~F}$ & DEAD \\
\hline AVE & 60.7 & & \\
\hline Median & 61 & & \\
\hline SD & 11.3 & & \\
\hline Females & & 12 & \\
\hline Males & & 17 & \\
\hline
\end{tabular}

\begin{tabular}{|c|l|l|l|}
\hline ICU 10+ days & & & \\
\hline Sample \# & Age & Sex & Outcome \\
\hline 227 & $41-50$ & $\mathrm{~F}$ & ALIVE \\
\hline 228 & $41-50$ & $\mathrm{M}$ & ALIVE \\
\hline 229 & $41-50$ & $\mathrm{M}$ & ALIVE \\
\hline 230 & $51-60$ & $\mathrm{~F}$ & ALIVE \\
\hline 231 & $51-60$ & $\mathrm{~F}$ & ALIVE \\
\hline 232 & $51-60$ & $\mathrm{~F}$ & ALIVE \\
\hline 233 & $51-60$ & $\mathrm{~F}$ & ALIVE \\
\hline 234 & $51-60$ & $\mathrm{M}$ & ALIVE \\
\hline 235 & $61-70$ & $\mathrm{~F}$ & ALIVE \\
\hline 236 & $61-70$ & $\mathrm{~F}$ & ALIVE \\
\hline 237 & $61-70$ & $\mathrm{~F}$ & ALIVE \\
\hline
\end{tabular}


medRxiv preprint doi: https://doi.org/10.1101/2022.01.10.21268250; this version posted January 11, 2022. The copyright holder for this preprint (which was not certified by peer review) is the author/funder, who has granted medRxiv a license to display the preprint in perpetuity.

\begin{tabular}{|l|l|l|l|}
\multicolumn{1}{|r|}{238} & $61-70$ & $\mathrm{M}$ & ALIVE \\
\hline 239 & $61-70$ & $\mathrm{M}$ & ALIVE \\
\hline 240 & $71-80$ & $\mathrm{~F}$ & ALIVE \\
\hline AVE & 58.3 & & \\
\hline Median & 56 & & \\
\hline SD & 8.5 & & \\
\hline Females & & 9 & \\
\hline Males & & 6 & \\
\hline
\end{tabular}

526

527 
medRxiv preprint doi: https://doi.org/10.1101/2022.01.10.21268250; this version posted January 11, 2022. The copyright holder for this preprint (which was not certified by peer review) is the author/funder, who has granted medRxiv a license to display the preprint in perpetuity.

All rights reserved. No reuse allowed without permission.

528 Table S4. Links to sample NIBSC/WHO information.

\begin{tabular}{|c|c|c|}
\hline $\begin{array}{l}\text { Study } \\
\text { Assigned }\end{array}$ & NIBSC/WHO & Website link \\
\hline Sample ID & Sample ID & 530 \\
\hline 335 & 20/B770-1 & https://www.nibsc.org/documents/ifu/20-B770.pdf \\
\hline 336 & 20/B770-2 & https://www.nibsc.org/documents/ifu/20-B770.pdf \\
\hline 337 & 20/B770-3 & https://www.nibsc.org/documents/ifu/20-B770.pdf \\
\hline 338 & 20/B770-4 & https://www.nibsc.org/documents/ifu/20-B770.pdf \\
\hline 339 & 20/B770-5 & https://www.nibsc.org/documents/ifu/20-B770.pdf \\
\hline 340 & 20/B770-6 & https://www.nibsc.org/documents/ifu/20-B770.pdf \\
\hline 341 & 20/B770-7 & https://www.nibsc.org/documents/ifu/20-B770.pdf \\
\hline 342 & 20/B770-8 & https://www.nibsc.org/documents/ifu/20-B770.pdf \\
\hline 343 & 20/B770-9 & https://www.nibsc.org/documents/ifu/20-B770.pdf \\
\hline 344 & 20/B770-10 & https://www.nibsc.org/documents/ifu/20-B770.pdf \\
\hline 345 & 20/B770-11 & https://www.nibsc.org/documents/ifu/20-B770.pdf \\
\hline 346 & 20/B770-12 & https://www.nibsc.org/documents/ifu/20-B770.pdf \\
\hline 347 & 20/B770-13 & https://www.nibsc.org/documents/ifu/20-B770.pdf \\
\hline 348 & 20/B770-14 & https://www.nibsc.org/documents/ifu/20-B770.pdf \\
\hline 349 & 20/B770-15 & https://www.nibsc.org/documents/ifu/20-B770.pdf \\
\hline 350 & 20/B770-16 & https://www.nibsc.org/documents/ifu/20-B770.pdf \\
\hline 351 & 20/B770-17 & https://www.nibsc.org/documents/ifu/20-B770.pdf \\
\hline 352 & 20/B770-18 & https://www.nibsc.org/documents/ifu/20-B770.pdf \\
\hline 353 & 20/B770-19 & https://www.nibsc.org/documents/ifu/20-B770.pdf \\
\hline 354 & 20/B770-20 & https://www.nibsc.org/documents/ifu/20-B770.pdf \\
\hline 355 & 20/B770-21 & https://www.nibsc.org/documents/ifu/20-B770.pdf \\
\hline 356 & 20/B770-22 & https://www.nibsc.org/documents/ifu/20-B770.pdf \\
\hline 357 & 20/B770-23 & https://www.nibsc.org/documents/ifu/20-B770.pdf \\
\hline 327 & $20 / 130$ & https://www.nibsc.org/documents/ifu/20-130.pdf \\
\hline 328 & $20 / 162$ & https://www.nibsc.org/documents/ifu/20-162.pdf \\
\hline 329 & 20/B764-01 & https://www.nibsc.org/documents/ifu/20-B764-xxx.pdf \\
\hline 330 & $20 / 136$ & https://www.nibsc.org/documents/ifu/20-136.pdf \\
\hline 331 & $20 / 140$ & https://www.nibsc.org/documents/ifu/20-268.pdf \\
\hline 332 & $20 / 144$ & https://www.nibsc.org/documents/ifu/20-268.pdf \\
\hline 333 & $20 / 148$ & https://www.nibsc.org/documents/ifu/20-268.pdf \\
\hline 334 & $20 / 150$ & https://www.nibsc.org/documents/ifu/20-268.pdf \\
\hline
\end{tabular}


medRxiv preprint doi: https://doi.org/10.1101/2022.01.10.21268250; this version posted January 11, 2022. The copyright holder for this preprint (which was not certified by peer review) is the author/funder, who has granted medRxiv a license to display the preprint in perpetuity.

All rights reserved. No reuse allowed without permission.

531 Table S5. Evaluation of Neutralizing Antibodies Detection by Anti-SARS-CoV-2 DBC Serological tests.

532 Results of testing samples from 4 sources on GenScript cPass ${ }^{\text {TM }}$ SARS-CoV-2 Neutralization Antibody

533 Detection/Surrogate Virus Neutralization Test Kit and DBC IgG anti-SARS-CoV-2 authorized serological

534 test. Samples were sourced from (1) infected individuals PCR proven to be SARS-CoV-2 positive, (2) COVID-

53519 infected ICU patients, (3) fully vaccinated individuals (two doses of either Pfizer or Moderna vaccines), and

536 (4) Reference samples from NIBSC/WHO. For the GenScript kit, a Positive outcome was considered at $\geq 30 \%$.

537 For the DBC kits, a Positive outcome was considered at a ratio of $>1.2$, Borderline 1.2-1.0, and Negative $<1.0$.

\begin{tabular}{|c|c|c|c|c|c|}
\hline \multirow{4}{*}{$\begin{array}{c}\text { Sample } \\
I D\end{array}$} & \multirow{3}{*}{$\begin{array}{c}\text { Sample } \\
\text { Origin }\end{array}$} & \multicolumn{2}{|l|}{ GenScript } & \multicolumn{2}{|l|}{ DBC } \\
\hline & & \multicolumn{2}{|c|}{ Neutralizing Antibodies } & \multicolumn{2}{|c|}{ IgG ELISA } \\
\hline & & \multicolumn{2}{|c|}{$\begin{array}{l}<30 \% \text { Negative } \\
\geq 30 \% \text { Positive }\end{array}$} & \multicolumn{2}{|c|}{$\begin{array}{l}<1 \text { Negative } \\
>1.2 \text { Positive }\end{array}$} \\
\hline & & $\%$ NeutAbs & Diagnosis & Ratio & Diagnosis \\
\hline 161 & 1 & 95.9 & POSITIVE & 9.7 & POSITIVE \\
\hline 162 & 1 & 17.5 & NEGATIVE & 1.1 & BORD \\
\hline 163 & 1 & 47.7 & POSITIVE & 2.4 & POSITIVE \\
\hline 164 & 1 & 44.3 & POSITIVE & 3.4 & POSITIVE \\
\hline 165 & 1 & 76.1 & POSITIVE & 5.1 & POSITIVE \\
\hline 166 & 1 & 34.1 & POSITIVE & 1.1 & BORD \\
\hline 167 & 1 & 84.8 & POSITIVE & 9.5 & POSITIVE \\
\hline 168 & 1 & 22.8 & NEGATIVE & 1.2 & BORD \\
\hline 169 & 1 & 96.3 & POSITIVE & 12.6 & POSITIVE \\
\hline 170 & 1 & 85.3 & POSITIVE & 5.0 & POSITIVE \\
\hline 171 & 1 & 23.5 & NEGATIVE & 1.7 & POSITIVE \\
\hline 172 & 1 & 89.8 & POSITIVE & 8.9 & POSITIVE \\
\hline 173 & 1 & 47.2 & POSITIVE & 2.8 & POSITIVE \\
\hline 174 & 1 & 80.1 & POSITIVE & 9.1 & POSITIVE \\
\hline 175 & 1 & 14.3 & NEGATIVE & 1.1 & BORD \\
\hline 176 & 1 & 75.8 & POSITIVE & 3.9 & POSITIVE \\
\hline 177 & 1 & 97.4 & POSITIVE & 7.2 & POSITIVE \\
\hline 178 & 1 & 63.7 & POSITIVE & 5.4 & POSITIVE \\
\hline 179 & 1 & 64.8 & POSITIVE & 2.3 & POSITIVE \\
\hline 180 & 1 & 94.2 & POSITIVE & 13.2 & POSITIVE \\
\hline 181 & 1 & 48.1 & POSITIVE & 1.9 & POSITIVE \\
\hline 182 & 1 & 92.4 & POSITIVE & 18.0 & POSITIVE \\
\hline 183 & 1 & 95.6 & POSITIVE & 13.4 & POSITIVE \\
\hline 184 & 1 & 90.6 & POSITIVE & 9.9 & POSITIVE \\
\hline 185 & 1 & 92.4 & POSITIVE & 7.7 & POSITIVE \\
\hline 186 & 1 & 69.7 & POSITIVE & 2.8 & POSITIVE \\
\hline 187 & 1 & 88.5 & POSITIVE & 4.6 & POSITIVE \\
\hline
\end{tabular}


medRxiv preprint doi: https://doi.org/10.1101/2022.01.10.21268250; this version posted January 11, 2022. The copyright holder for this preprint (which was not certified by peer review) is the author/funder, who has granted medRxiv a license to display the preprint in perpetuity.

All rights reserved. No reuse allowed without permission.

\begin{tabular}{|c|c|c|c|c|c|}
\hline 188 & 1 & 61.6 & POSITIVE & 7.4 & POSITIVE \\
\hline 189 & 1 & 46.9 & POSITIVE & 2.6 & POSITIVE \\
\hline 190 & 1 & 77.1 & POSITIVE & 7.1 & POSITIVE \\
\hline 191 & 1 & 88.5 & POSITIVE & 7.9 & POSITIVE \\
\hline 192 & 1 & 92.8 & POSITIVE & 11.9 & POSITIVE \\
\hline 193 & 1 & 91.0 & POSITIVE & 14.4 & POSITIVE \\
\hline 194 & 1 & 94.7 & POSITIVE & 13.2 & POSITIVE \\
\hline 195 & 1 & 52.0 & POSITIVE & 2.2 & POSITIVE \\
\hline 196 & 1 & 76.7 & POSITIVE & 4.2 & POSITIVE \\
\hline 197 & 1 & 94.0 & POSITIVE & 15.4 & POSITIVE \\
\hline 241 & 1 & 58.3 & POSITIVE & 3.7 & POSITIVE \\
\hline 242 & 1 & 96.1 & POSITIVE & 20.0 & POSITIVE \\
\hline 243 & 1 & 63.8 & POSITIVE & 9.2 & POSITIVE \\
\hline 244 & 1 & 93.7 & POSITIVE & 14.6 & POSITIVE \\
\hline 245 & 1 & 47.1 & POSITIVE & 5.8 & POSITIVE \\
\hline 246 & 1 & 68.4 & POSITIVE & 6.6 & POSITIVE \\
\hline 247 & 1 & 73.2 & POSITIVE & 6.5 & POSITIVE \\
\hline 248 & 1 & 72.1 & POSITIVE & 7.9 & POSITIVE \\
\hline 249 & 1 & 67.5 & POSITIVE & 7.3 & POSITIVE \\
\hline 250 & 1 & 67.9 & POSITIVE & 6.5 & POSITIVE \\
\hline 251 & 1 & 90.9 & POSITIVE & 17.2 & POSITIVE \\
\hline 252 & 1 & 32.1 & POSITIVE & 1.1 & BORD \\
\hline 253 & 1 & 54.5 & POSITIVE & 4.5 & POSITIVE \\
\hline 254 & 1 & 71.7 & POSITIVE & 2.7 & POSITIVE \\
\hline 198 & 2 & 91.9 & POSITIVE & 17.2 & POSITIVE \\
\hline 200 & 2 & 97.5 & POSITIVE & 25.0 & POSITIVE \\
\hline 202 & 2 & 90.3 & POSITIVE & 21.0 & POSITIVE \\
\hline 204 & 2 & 96.9 & POSITIVE & 25.6 & POSITIVE \\
\hline 205 & 2 & 81.8 & POSITIVE & 11.4 & POSITIVE \\
\hline 206 & 2 & 94.2 & POSITIVE & 22.2 & POSITIVE \\
\hline 207 & 2 & 94.2 & POSITIVE & 23.6 & POSITIVE \\
\hline 208 & 2 & 48.8 & POSITIVE & 4.0 & POSITIVE \\
\hline 209 & 2 & 80.4 & POSITIVE & 13.7 & POSITIVE \\
\hline 210 & 2 & 22.0 & NEGATIVE & 1.1 & BORD \\
\hline 211 & 2 & 84.0 & POSITIVE & 15.6 & POSITIVE \\
\hline 214 & 2 & 77.0 & POSITIVE & 7.0 & POSITIVE \\
\hline 215 & 2 & 82.9 & POSITIVE & 16.3 & POSITIVE \\
\hline 216 & 2 & 96.5 & POSITIVE & 26.5 & POSITIVE \\
\hline 218 & 2 & 19.3 & NEGATIVE & 0.5 & NEGATIVE \\
\hline 219 & 2 & 94.8 & POSITIVE & 24.5 & POSITIVE \\
\hline 220 & 2 & 93.0 & POSITIVE & 25.2 & POSITIVE \\
\hline
\end{tabular}


medRxiv preprint doi: https://doi.org/10.1101/2022.01.10.21268250; this version posted January 11, 2022. The copyright holder for this preprint (which was not certified by peer review) is the author/funder, who has granted medRxiv a license to display the preprint in perpetuity.

All rights reserved. No reuse allowed without permission.

\begin{tabular}{|c|c|c|c|c|c|}
\hline 221 & 2 & 86.1 & POSITIVE & 13.2 & POSITIVE \\
\hline 223 & 2 & 95.6 & POSITIVE & 21.3 & POSITIVE \\
\hline 224 & 2 & 83.4 & POSITIVE & 8.6 & POSITIVE \\
\hline 226 & 2 & 91.1 & POSITIVE & 9.2 & POSITIVE \\
\hline 227 & 2 & 90.9 & POSITIVE & 9.8 & POSITIVE \\
\hline 240 & 2 & 95.9 & POSITIVE & 25.0 & POSITIVE \\
\hline 255 & 2 & 46.6 & POSITIVE & 1.1 & BORD \\
\hline 256 & 2 & 84.6 & POSITIVE & 12.9 & POSITIVE \\
\hline 257 & 2 & 97.7 & POSITIVE & 23.2 & POSITIVE \\
\hline 258 & 2 & 96.7 & POSITIVE & 23.8 & POSITIVE \\
\hline 259 & 2 & 93.6 & POSITIVE & 17.8 & POSITIVE \\
\hline 260 & 2 & 94.6 & POSITIVE & 23.1 & POSITIVE \\
\hline 261 & 2 & 37.6 & POSITIVE & 17.6 & POSITIVE \\
\hline 262 & 2 & 96.5 & POSITIVE & 26.1 & POSITIVE \\
\hline 263 & 2 & 94.5 & POSITIVE & 25.8 & POSITIVE \\
\hline 264 & 2 & 78.4 & POSITIVE & 10.9 & POSITIVE \\
\hline 265 & 2 & 16.4 & NEGATIVE & 0.6 & NEGATIVE \\
\hline 266 & 2 & 36.6 & POSITIVE & 1.4 & POSITIVE \\
\hline 267 & 2 & 89.2 & POSITIVE & 13.8 & POSITIVE \\
\hline 268 & 2 & 19.2 & NEGATIVE & 1.3 & POSITIVE \\
\hline 269 & 3 & 95.4 & POSITIVE & 25.0 & POSITIVE \\
\hline 270 & 3 & 98.1 & POSITIVE & 25.0 & POSITIVE \\
\hline 271 & 3 & 97.4 & POSITIVE & 18.8 & POSITIVE \\
\hline 272 & 3 & 95.2 & POSITIVE & 15.3 & POSITIVE \\
\hline 273 & 3 & 98.2 & POSITIVE & 21.7 & POSITIVE \\
\hline 274 & 3 & 98.1 & POSITIVE & 25.0 & POSITIVE \\
\hline 275 & 3 & 53.6 & POSITIVE & 5.4 & POSITIVE \\
\hline 276 & 3 & 96.1 & POSITIVE & 23.0 & POSITIVE \\
\hline 277 & 3 & 97.8 & POSITIVE & 22.6 & POSITIVE \\
\hline 278 & 3 & 97.6 & POSITIVE & 23.0 & POSITIVE \\
\hline 279 & 3 & 98.0 & POSITIVE & 25.0 & POSITIVE \\
\hline 280 & 3 & 98.1 & POSITIVE & 25.0 & POSITIVE \\
\hline 281 & 3 & 98.0 & POSITIVE & 22.2 & POSITIVE \\
\hline 282 & 3 & 97.7 & POSITIVE & 22.6 & POSITIVE \\
\hline 283 & 3 & 98.0 & POSITIVE & 25.0 & POSITIVE \\
\hline 284 & 3 & 98.0 & POSITIVE & 21.0 & POSITIVE \\
\hline 285 & 3 & 98.0 & POSITIVE & 23.1 & POSITIVE \\
\hline 286 & 3 & 98.2 & POSITIVE & 25.0 & POSITIVE \\
\hline 287 & 3 & 98.2 & POSITIVE & 25.0 & POSITIVE \\
\hline 288 & 3 & 97.7 & POSITIVE & 19.7 & POSITIVE \\
\hline 289 & 3 & 98.1 & POSITIVE & 25.0 & POSITIVE \\
\hline
\end{tabular}


medRxiv preprint doi: https://doi.org/10.1101/2022.01.10.21268250; this version posted January 11, 2022. The copyright holder for this preprint (which was not certified by peer review) is the author/funder, who has granted medRxiv a license to display the preprint in perpetuity.

All rights reserved. No reuse allowed without permission.

\begin{tabular}{|c|c|c|c|c|c|}
\hline 290 & 3 & 98.0 & POSITIVE & 21.8 & POSITIVE \\
\hline 291 & 3 & 98.1 & POSITIVE & 23.0 & POSITIVE \\
\hline 292 & 3 & 98.1 & POSITIVE & 22.9 & POSITIVE \\
\hline 293 & 3 & 97.5 & POSITIVE & 18.2 & POSITIVE \\
\hline 294 & 3 & 98.2 & POSITIVE & 25.0 & POSITIVE \\
\hline 295 & 3 & 98.1 & POSITIVE & 25.0 & POSITIVE \\
\hline 296 & 3 & 98.0 & POSITIVE & 23.0 & POSITIVE \\
\hline 297 & 3 & 98.2 & POSITIVE & 22.0 & POSITIVE \\
\hline 298 & 3 & 98.2 & POSITIVE & 25.0 & POSITIVE \\
\hline 299 & 3 & 98.2 & POSITIVE & 22.6 & POSITIVE \\
\hline 300 & 3 & 98.0 & POSITIVE & 22.7 & POSITIVE \\
\hline 301 & 3 & 97.5 & POSITIVE & 22.7 & POSITIVE \\
\hline 302 & 3 & 97.6 & POSITIVE & 22.6 & POSITIVE \\
\hline 303 & 3 & 98.2 & POSITIVE & 25.0 & POSITIVE \\
\hline 304 & 3 & 98.0 & POSITIVE & 25.0 & POSITIVE \\
\hline 305 & 3 & 98.0 & POSITIVE & 23.1 & POSITIVE \\
\hline 306 & 3 & 98.1 & POSITIVE & 23.1 & POSITIVE \\
\hline 307 & 3 & 98.2 & POSITIVE & 25.0 & POSITIVE \\
\hline 308 & 3 & 98.1 & POSITIVE & 25.0 & POSITIVE \\
\hline 309 & 3 & 98.2 & POSITIVE & 23.2 & POSITIVE \\
\hline 310 & 3 & 98.2 & POSITIVE & 25.0 & POSITIVE \\
\hline 311 & 3 & 97.9 & POSITIVE & 23.2 & POSITIVE \\
\hline 312 & 3 & 98.2 & POSITIVE & 25.0 & POSITIVE \\
\hline 313 & 3 & 96.5 & POSITIVE & 19.6 & POSITIVE \\
\hline 314 & 3 & 93.1 & POSITIVE & 16.5 & POSITIVE \\
\hline 315 & 3 & 98.2 & POSITIVE & 22.7 & POSITIVE \\
\hline 316 & 3 & 98.1 & POSITIVE & 22.9 & POSITIVE \\
\hline 317 & 3 & 96.4 & POSITIVE & 19.4 & POSITIVE \\
\hline 318 & 3 & 98.0 & POSITIVE & 22.2 & POSITIVE \\
\hline 319 & 3 & 97.5 & POSITIVE & 25.0 & POSITIVE \\
\hline 320 & 3 & 98.0 & POSITIVE & 25.0 & POSITIVE \\
\hline 321 & 3 & 90.7 & POSITIVE & 21.0 & POSITIVE \\
\hline 322 & 3 & 98.2 & POSITIVE & 25.0 & POSITIVE \\
\hline 323 & 3 & 98.0 & POSITIVE & 23.3 & POSITIVE \\
\hline 324 & 3 & 98.1 & POSITIVE & 25.0 & POSITIVE \\
\hline 325 & 3 & 97.5 & POSITIVE & 23.1 & POSITIVE \\
\hline 326 & 3 & 98.2 & POSITIVE & 25.0 & POSITIVE \\
\hline 327 & 4 & 90.4 & POSITIVE & 9.5 & POSITIVE \\
\hline 328 & 4 & 98.1 & POSITIVE & 15.0 & POSITIVE \\
\hline 329 & 4 & 34.7 & POSITIVE & 1.9 & POSITIVE \\
\hline 330 & 4 & 96.2 & POSITIVE & 12.1 & POSITIVE \\
\hline
\end{tabular}


medRxiv preprint doi: https://doi.org/10.1101/2022.01.10.21268250; this version posted January 11, 2022. The copyright holder for this preprint (which was not certified by peer review) is the author/funder, who has granted medRxiv a license to display the preprint in perpetuity.

All rights reserved. No reuse allowed without permission.

\begin{tabular}{|c|c|c|c|c|c|}
\hline 331 & 4 & 19.0 & NEGATIVE & 1.6 & POSITIVE \\
\hline 332 & 4 & 36.1 & POSITIVE & 1.7 & POSITIVE \\
\hline 333 & 4 & 81.4 & POSITIVE & 5.9 & POSITIVE \\
\hline 334 & 4 & 90.1 & POSITIVE & 11.1 & POSITIVE \\
\hline 335 & 4 & 44.8 & POSITIVE & 1.6 & POSITIVE \\
\hline 336 & 4 & 44.9 & POSITIVE & 2.4 & POSITIVE \\
\hline 337 & 4 & 97.3 & POSITIVE & 12.3 & POSITIVE \\
\hline 338 & 4 & 94.6 & POSITIVE & 11.8 & POSITIVE \\
\hline 339 & 4 & 97.4 & POSITIVE & 12.4 & POSITIVE \\
\hline 340 & 4 & 83.3 & POSITIVE & 10.1 & POSITIVE \\
\hline 341 & 4 & 86.7 & POSITIVE & 7.5 & POSITIVE \\
\hline 342 & 4 & 95.8 & POSITIVE & 10.5 & POSITIVE \\
\hline 343 & 4 & 52.0 & POSITIVE & 11.3 & POSITIVE \\
\hline 344 & 4 & 51.7 & POSITIVE & 11.0 & POSITIVE \\
\hline 345 & 4 & 87.4 & POSITIVE & 4.5 & POSITIVE \\
\hline 346 & 4 & 84.2 & POSITIVE & 4.7 & POSITIVE \\
\hline 347 & 4 & 86.7 & POSITIVE & 5.1 & POSITIVE \\
\hline 348 & 4 & 81.9 & POSITIVE & 4.0 & POSITIVE \\
\hline 349 & 4 & 90.3 & POSITIVE & 5.8 & POSITIVE \\
\hline 350 & 4 & 74.7 & POSITIVE & 2.7 & POSITIVE \\
\hline 351 & 4 & 88.8 & POSITIVE & 7.6 & POSITIVE \\
\hline 352 & 4 & 95.6 & POSITIVE & 11.3 & POSITIVE \\
\hline 353 & 4 & 85.1 & POSITIVE & 6.7 & POSITIVE \\
\hline 354 & 4 & 95.5 & POSITIVE & 6.4 & POSITIVE \\
\hline 355 & 4 & 94.7 & POSITIVE & 8.9 & POSITIVE \\
\hline 356 & 4 & 95.5 & POSITIVE & 7.1 & POSITIVE \\
\hline 357 & 4 & 91.3 & POSITIVE & 7.8 & POSITIVE \\
\hline
\end{tabular}


medRxiv preprint doi: https://doi.org/10.1101/2022.01.10.21268250; this version posted January 11, 2022. The copyright holder for this preprint (which was not certified by peer review) is the author/funder, who has granted medRxiv a license to display the preprint in perpetuity. All rights reserved. No reuse allowed without permission.

550
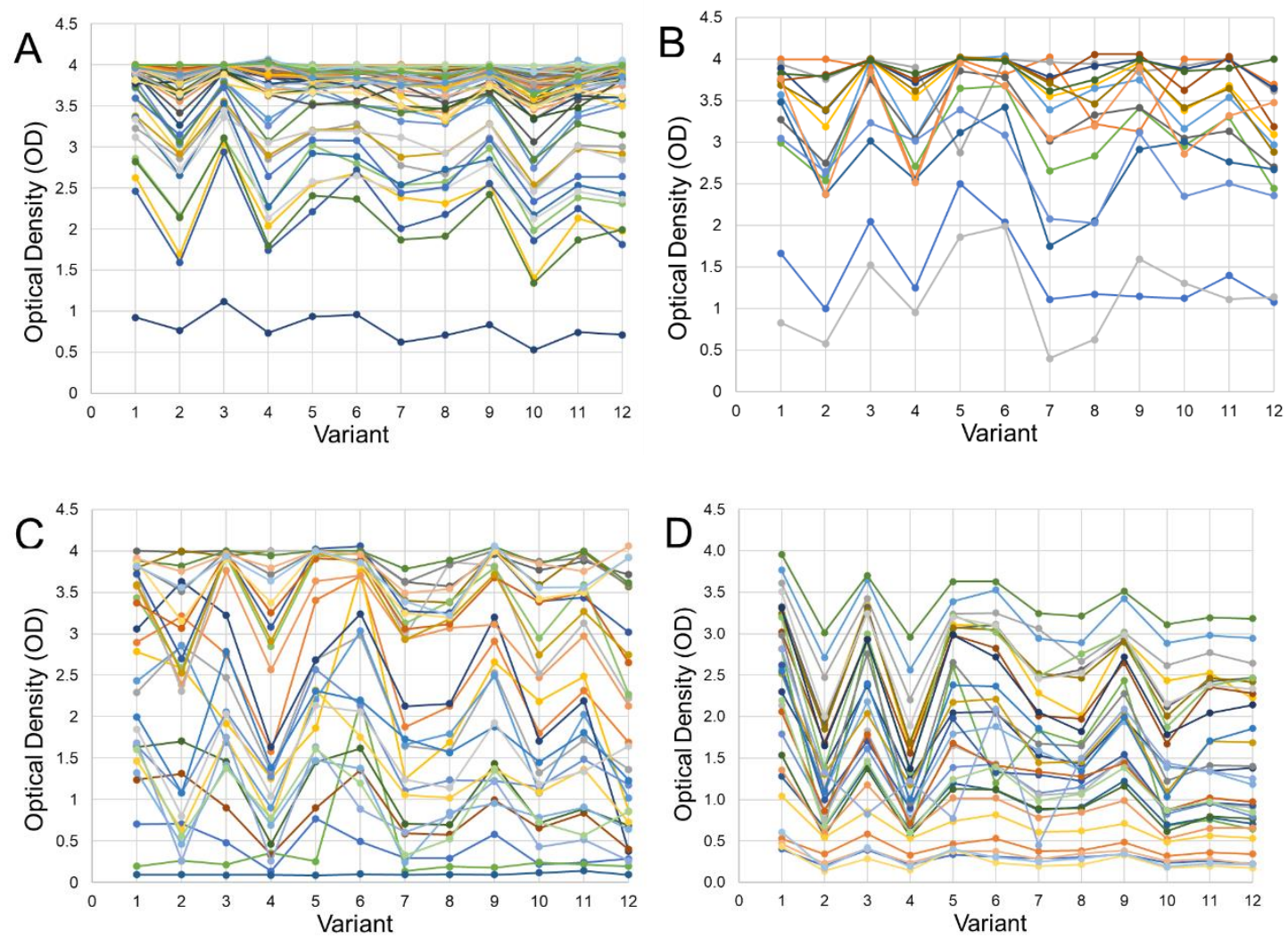

551

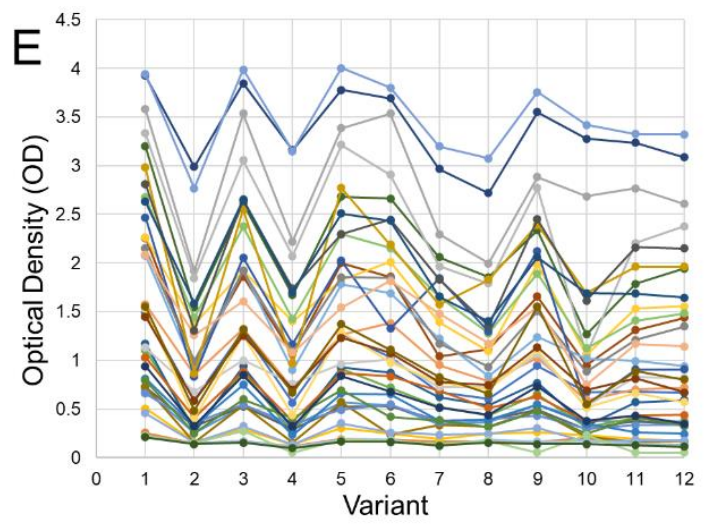

\begin{tabular}{|l|l|}
\hline 1 & WT \\
\hline 2 & K417N-E484K-N501Y \\
\hline 3 & N501Y \\
\hline 4 & K417T, E484K, N501Y \\
\hline 5 & K417T \\
\hline 6 & L452R \\
\hline 7 & Y453F \\
\hline 8 & N439K \\
\hline 9 & S477N \\
\hline 10 & L452R, E484Q \\
\hline 11 & L452R, T478K \\
\hline 12 & K417N, L452R, T478K \\
\hline
\end{tabular}

Figure S1. Individual variability in vaccine and convalescence sera reactivity to WT SARS-CoV-2 RBD antigen

554 and antigens bearing mutations. Each line represents the optical density values from an individual donor.

555

A. Vaccinated, B. ICU patients $10+$ days,

C. ICU patients 2-7 days,

D. NIBSC/WHO (WHO) panel, E. Ambulatory and hospitalized (but not critically ill) population (AHP) panel. 
medRxiv preprint doi: https://doi.org/10.1101/2022.01.10.21268250; this version posted January 11, 2022. The copyright holder for this preprint (which was not certified by peer review) is the author/funder, who has granted medRxiv a license to display the preprint in perpetuity.

All rights reserved. No reuse allowed without permission.

\section{Descriptives}

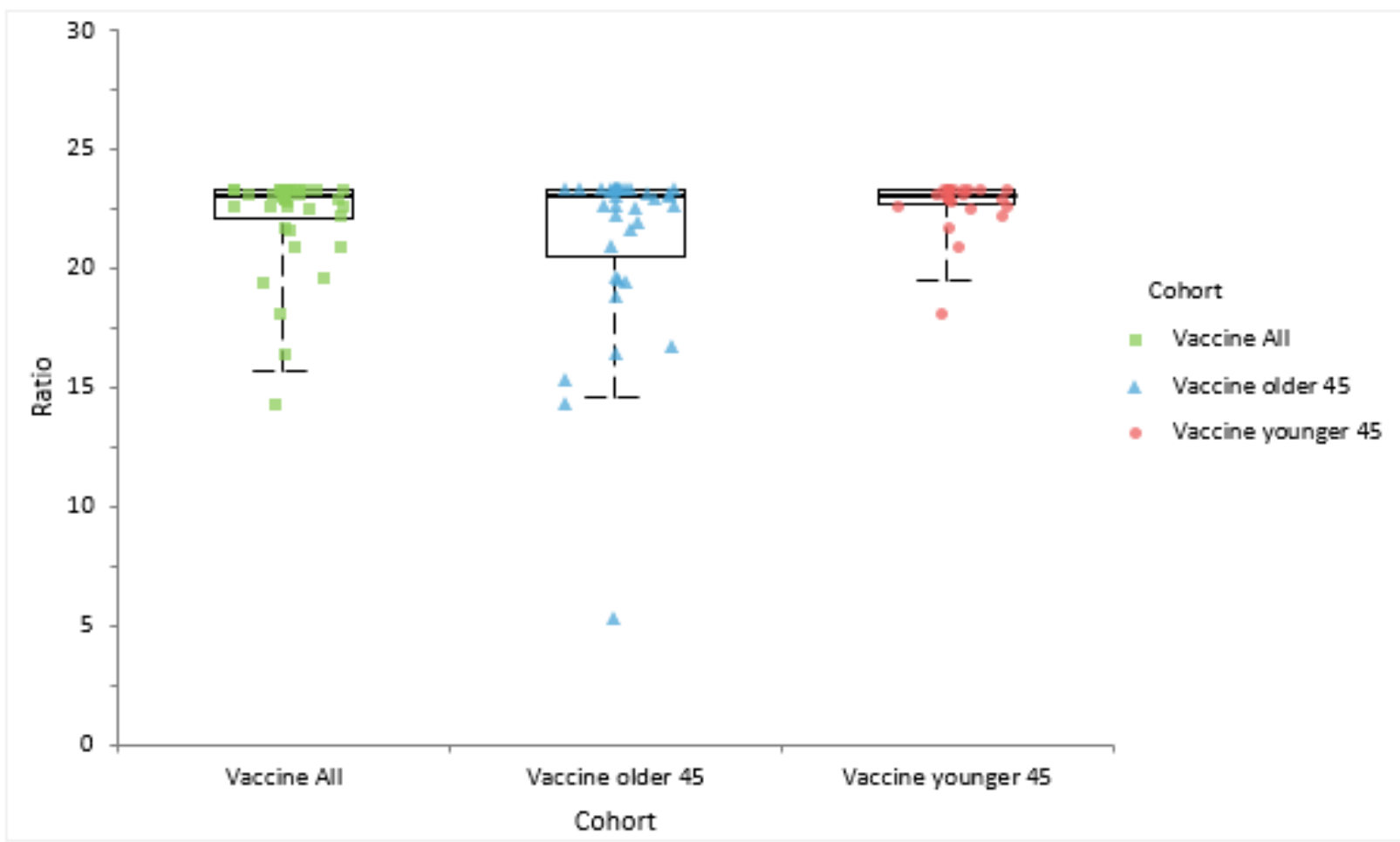

\section{Multiple Comparisons}

Steel-Dwass-Critchlow-Fligner all pairs comparisons

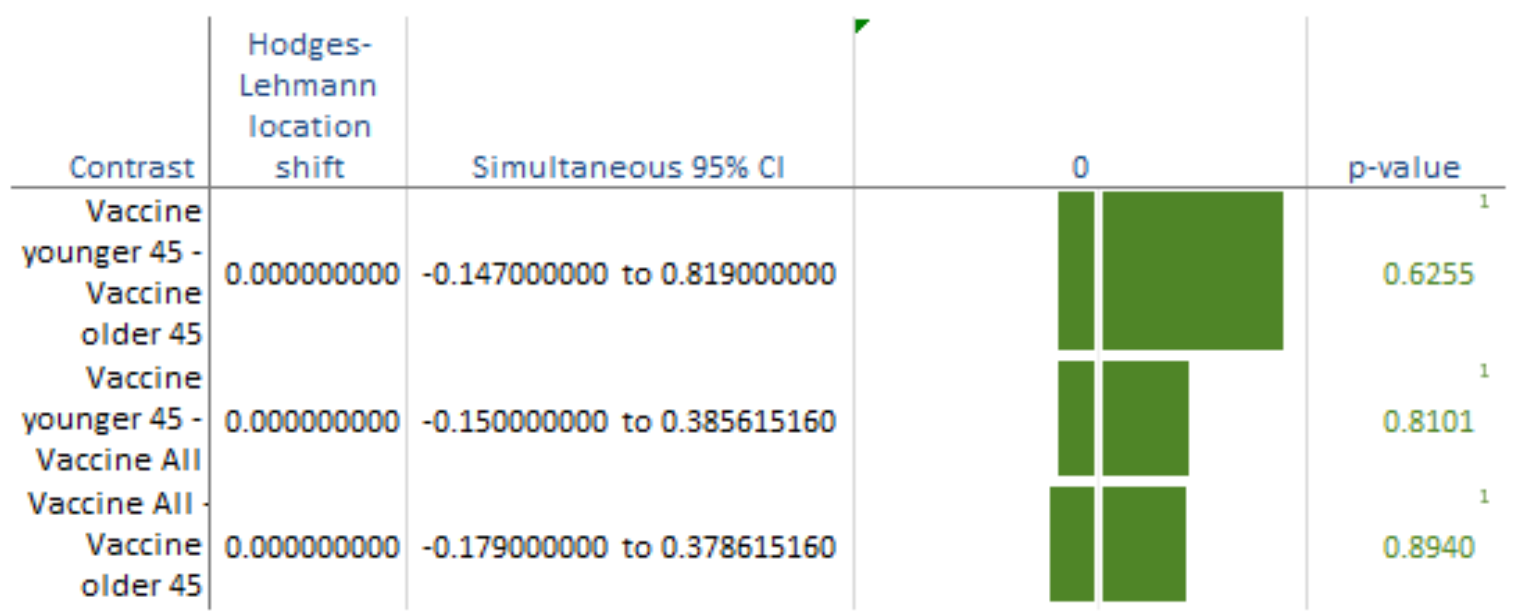

HO: $\theta=0$

The shift in location between the distributions of the populations is equal to 0 .

$H 1: \theta \neq 0$

The shift in location between the distributions of the populations is not equal to 0 .

${ }^{1}$ Do not reject the null hypothesis at the $5 \%$ significance level.

Figure S2. Reactivity of sera from vaccinated individuals (Vaccine) to a recombinant antigen comprising the

560 RBD of wild type (WT) SARS-CoV-2. The vaccine results were split in those older or younger than 45 years.

561 The median is plotted as a line. The box represents 1st to 3rd quartiles and the whiskers the minimum and 562 maximum of the $95 \%$ confidence interval. 
medRxiv preprint doi: https://doi.org/10.1101/2022.01.10.21268250; this version posted January 11, 2022. The copyright holder for this preprint (which was not certified by peer review) is the author/funder, who has granted medRxiv a license to display the preprint in perpetuity. All rights reserved. No reuse allowed without permission.

\section{Descriptives}

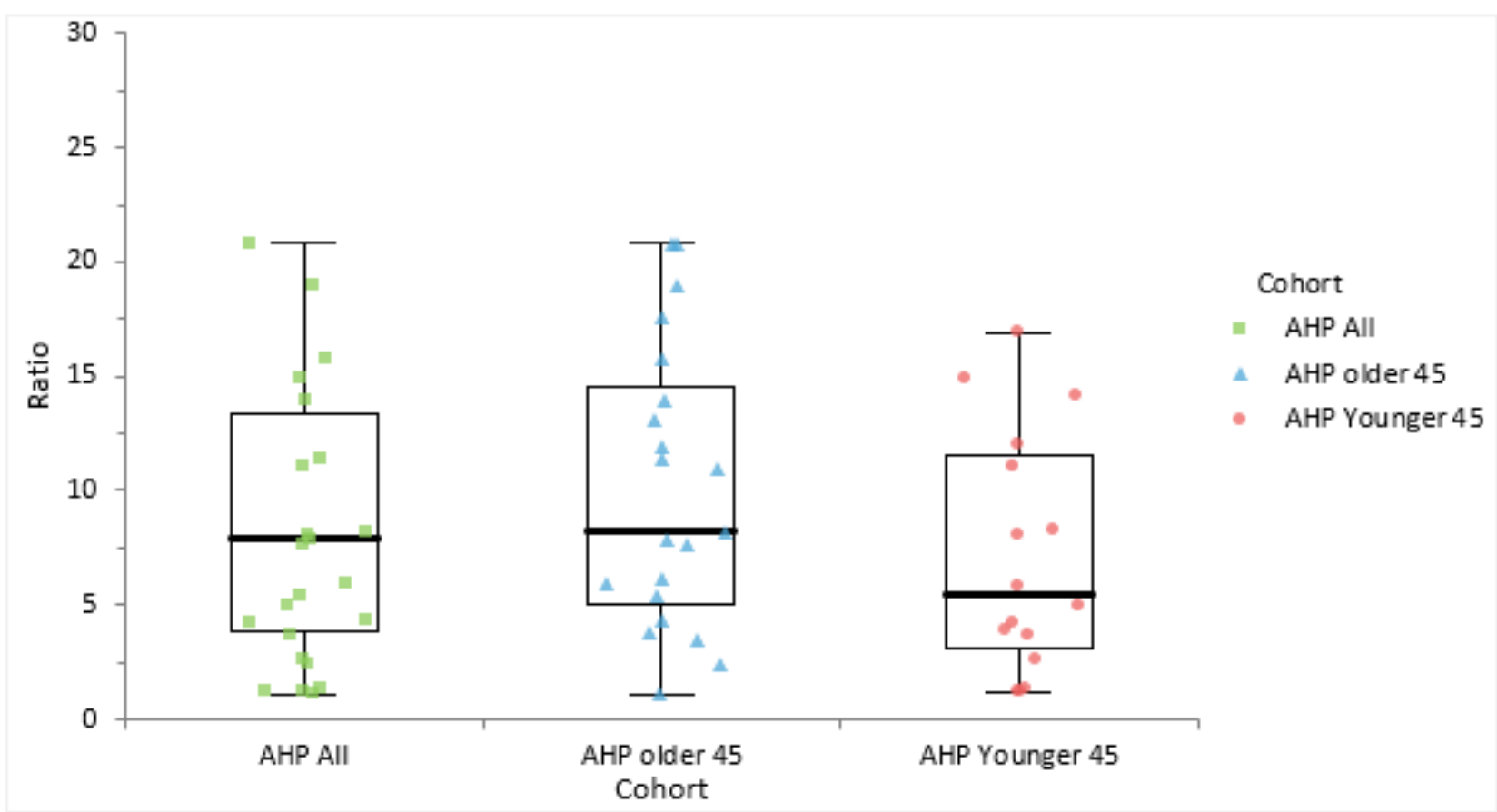

\section{Multiple Comparisons}

Steel-Dwass-Critchlow-Fligner all pairs comparisons

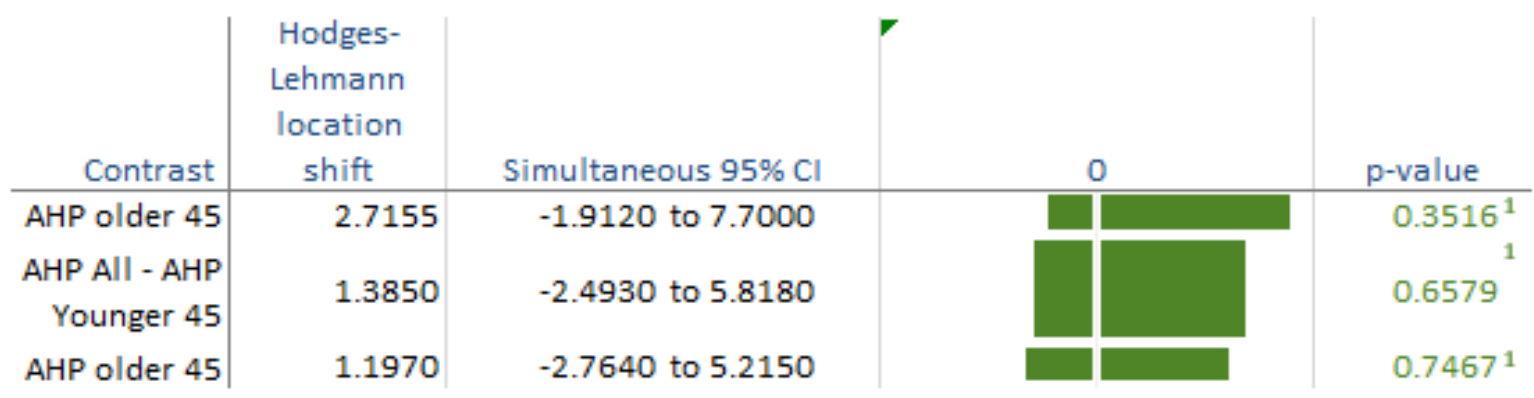

$\mathrm{H} 0: \theta=0$

The shift in location between the distributions of the populations is equal to 0 .

$\mathrm{H} 1: \theta \neq 0$

The shift in location between the distributions of the populations is not equal to 0 .

${ }^{1}$ Do not reject the null hypothesis at the $5 \%$ significance level.

Figure S3. Reactivity of sera from ambulatory and hospitalized, but not critically ill, population (AHP), to a recombinant antigen comprising the RBD of wild type (WT) SARS-CoV-2. The AHP results were split in those older or younger than 45 years. The median is plotted as a line. The box represents 1 st to 3 rd quartiles and the whiskers the minimum and maximum of the $95 \%$ confidence interval. 